\title{
How Do Polymer Coatings Affect the Growth and Bacterial Population of a Biofilm Formed by Total Human Salivary Bacteria?-A Study by 16S-RNA Sequencing
}

\author{
Ali Al-Ahmad 1,*(D), Kira Wollensak 1,2 (D), Sibylle Rau ${ }^{1}$, Diana Lorena Guevara Solarte ${ }^{1}$, Stefan Paschke ${ }^{2}$, \\ Karen Lienkamp ${ }^{2,3}$ and Ori Staszewski ${ }^{4}$ (D)
}

Citation: Al-Ahmad, A.; Wollensak, K.; Rau, S.; Guevara Solarte, D.L.; Paschke, S.; Lienkamp, K.; Staszewski, O. How Do Polymer Coatings Affect the Growth and Bacterial Population of a Biofilm Formed by Total Human Salivary Bacteria?-A Study by 16S-RNA Sequencing. Microorganisms 2021, 9, 1427. https://doi.org/10.3390/ microorganisms 9071427

Academic Editor: James S. Maki

Received: 1 April 2021

Accepted: 26 June 2021

Published: 1 July 2021

Publisher's Note: MDPI stays neutral with regard to jurisdictional claims in published maps and institutional affiliations.

Copyright: (c) 2021 by the authors. Licensee MDPI, Basel, Switzerland. This article is an open access article distributed under the terms and conditions of the Creative Commons Attribution (CC BY) license (https:// creativecommons.org/licenses/by/ $4.0 /)$.
1 Medical Center, Department of Operative Dentistry and Periodontology, Faculty of Medicine, University of Freiburg, Hugstetter Strasse 55, 79106 Freiburg, Germany; kirawollensak@yahoo.de (K.W.); sibylle.rau@uniklinik-freiburg.de (S.R.); diana.lorena.guevara.solarte@uniklinik-freiburg.de (D.L.G.S.)

2 Bioactive Polymer Synthesis and Surface Engineering Group, Department of Microsystems Engineering (IMTEK) and Freiburg Center for Interactive Materials and Bioinspired Technologies (FIT), University of Freiburg, Georges-Köhler-Allee 105, 79110 Freiburg, Germany; stefan.paschke@imtek.uni-freiburg.de (S.P.); karen.lienkamp@uni-saarland.de (K.L.)

3 Institut für Materialwissenschaft und Werkstoffkunde, Universität des Saarlandes, Campus, 66123 Saarbrücken, Germany

4 Medical Center, Institute of Neuropathology, Faculty of Medicine, University of Freiburg, 79106 Freiburg, Germany; ori.staszewski@uniklinik-freiburg.de

* Correspondence: ali.al-ahmad@uniklinik-freiburg.de; Tel.: +49-761-27048940

Abstract: Antimicrobial surface modifications are required to prevent biomaterial-associated biofilm infections, which are also a major concern for oral implants. The aim of this study was to evaluate the influence of three different coatings on the biofilm formed by human saliva. Biofilms grown from human saliva on three different bioactive poly(oxanorbornene)-based polymer coatings (the proteinrepellent PSB: poly(oxanorbornene)-based poly(sulfobetaine), the protein-repellent and antimicrobial PZI: poly(carboxyzwitterion), and the mildly antimicrobial and protein-adhesive SMAMP: synthetic mimics of antimicrobial peptides) were analyzed and compared with the microbial composition of saliva, biofilms grown on uncoated substrates, and biofilms grown in the presence of chlorhexidine digluconate. It was found that the polymer coatings significantly reduced the amount of adherent bacteria and strongly altered the microbial composition, as analyzed by $16 \mathrm{~S}$ RNA sequencing. This may hold relevance for maintaining oral health and the outcome of oral implants due to the existing synergism between the host and the oral microbiome. Especially the reduction of some bacterial species that are associated with poor oral health such as Tannerella forsythia and Fusobacterium nucleatum (observed for PSB and SMAMP), and Prevotella denticola (observed for all coatings) may positively modulate the oral biofilm, including in situ.

Keywords: implant-associated infections; biofilm; polymer coating; 16S RNA sequencing; antimicrobial surface modification

\section{Introduction}

Saliva and oral biofilms comprise a plethora of bacteria. A list of frequently-found genera and species in the oral cavity is included in Table 1. The most dominant groups are Streptococcus spp., which have been associated with dental caries [1], Actinomyces spp., which play a role in initial phase of caries development [2], Fusobacterium spp. (a bridging microorganism that can co-aggregate with early and late colonizers and hence plays a major role in the maturation of the oral biofilm), Veillonella spp. and Rothia spp. (which are considered as markers for early childhood caries) [3], Prevotella spp., Tannerella spp. and Porphyromonas spp. (associated with periodontitis patients) [4,5], Neisseria spp., and Gemella spp. [5], which affect the periodontal health status. While the dominant bacterial species 
are relatively similar among different people, the exact composition of the bacteria in saliva is individual and affected, for example, by a person's dietary habits and biochemical parameters of the saliva such as content of lysozyme and $\mathrm{pH}$ value $[1,6]$.

Thus, oral biofilms are involved in a number of dental diseases, among which caries and periodontitis are the most frequent [1,7]. A diverse array of acidogenic and aciduric species including Streptococcus mutans, Lactobacilli, Streptococcus salivarius, Actinomyces spp., Veillonella spp., and Atopobium spp. are involved in caries development [1,8]. Tannerella forsythia, Prevotella denticola, Filifactor alocis, Porphyromonas gingivalis and Aggregatibacter actinomycetemcomitans have been frequently associated with periodontitis $[9,10]$. Oral biofilms are also considered the cause of peri-implantitis, an oral implant-associated disease that is correlated with bone loss and subsequent treatment failure [11]. A shift in the subgingival oral biofilm composition with increased levels of Fusobacterium nucleatum, Porphyromonas gingivalis, Prevotella spp., and Tannerella forsythia has been shown to be associated with peri-implantitis [12,13]. From an ecological perspective, it should be emphasized that all oral infections are semi-specific and should be considered as cause of the total microbiota composition of the oral biofilm, rather than by specific species. The oral health status is the consequence of a subtle equilibrium between the host and the microbiota [14], whereby a destruction of this balance can lead to oral diseases such as caries, periodontitis, and peri-implantitis [11,15].

Oral biofilm formation is a process that is immediately initiated when a surface is in contact with human saliva. First, proteins and other organic and inorganic components of saliva adhere to the surface within seconds and form a "conditioning layer"- the so-called acquired pellicle-onto which later bacteria can settle [16]. Bacteria then use their own adhesive proteins to attach irreversibly to the surface. After an initial phase of adhesion, they start producing extracellular polymeric substances and form colonies of increasing diversity and thickness [17-19]. Colonies from different species form a joint extracellular matrix, which leads to the evolution of the mature biofilm [17-20]. Within the biofilm, bacteria are protected against the body's own immune system as well as against antibiotics [21-23]. This is why biofilm-induced infections, for example, of oral implants, are so problematic, given that a much higher concentration of antibiotics is needed to eradicate them [22,24].

It is well known from polymer science that a number of protein-repellent polymer coatings affect the initial adhesion of bacteria on surfaces [25-28], and that various antimicrobially active polymer coatings can kill bacteria [29-31]. In these studies, the effect of the coating on one bacterial species is typically evaluated, while their impact on mixed bacterial populations within biofilms is much less understood. Due to the relevance of bacterial biofilms in the loss of dental implants [11,12], the aim of this study was to ascertain whether and how polymer coatings affect biofilm formation and composition after incubating these materials with total human saliva. This should answer the question of whether and how the presence of bioactive polymer coatings affect the microbial population balance of bacteria in biofilms formed by total salivary bacteria, in particular whether the known oral health-associated equilibrium within the oral biofilm would be assisted or disturbed by such materials. This knowledge would allow scientists to assess the potential of such coatings for implantology.

For this purpose, three different polymer coatings were chosen, and oral bacteria from fresh saliva were cultivated on these surfaces. After an incubation time of three days, the biofilms were harvested from the surfaces, and their most abundant constituents were analyzed by 16S-RNA sequencing. 
Table 1. Important bacterial genera and species found in the human oral cavity, and their association with oral health or diseases.

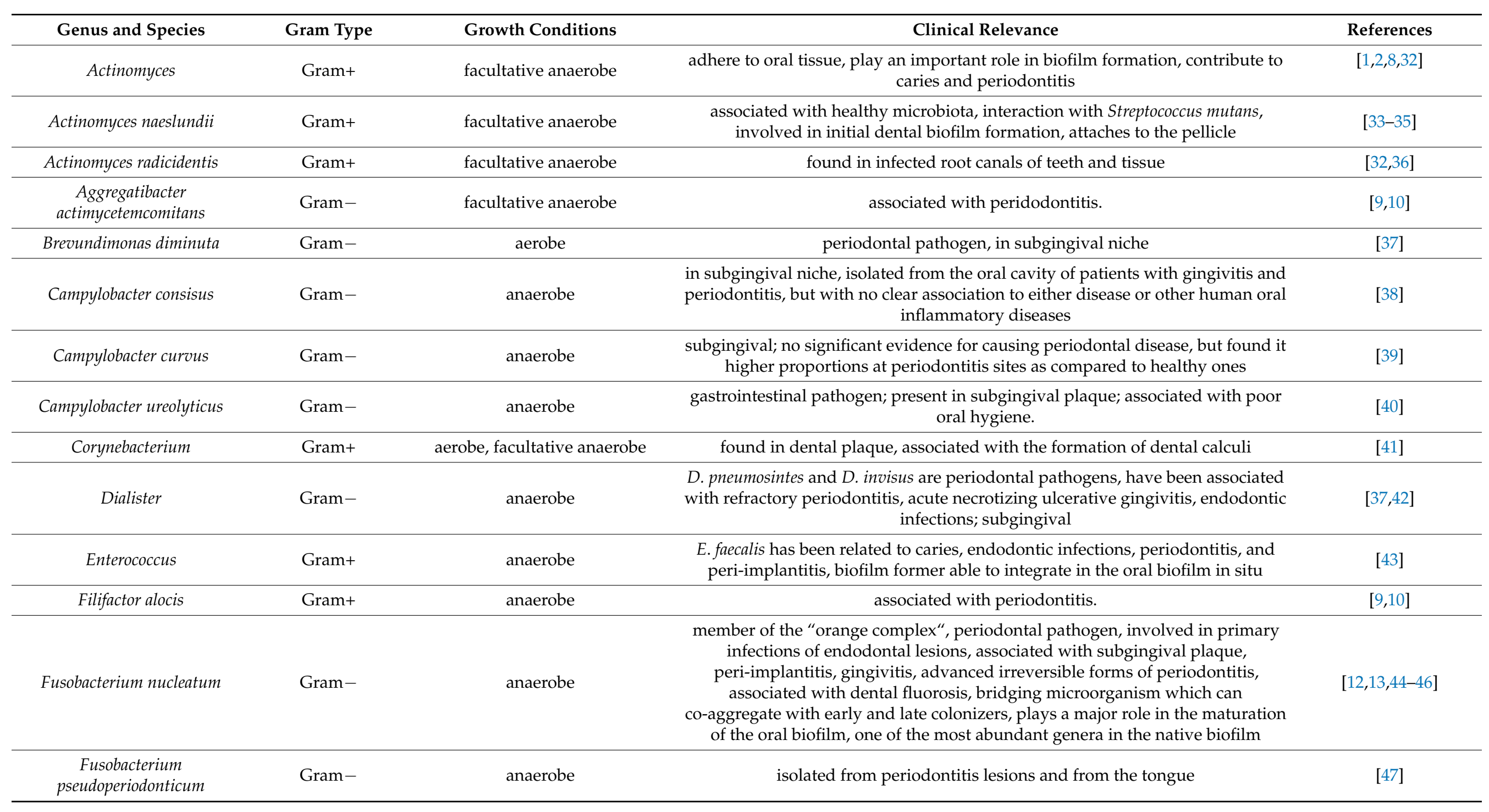


Table 1. Cont.

\begin{tabular}{|c|c|c|c|c|}
\hline Genus and Species & Gram Type & Growth Conditions & Clinical Relevance & References \\
\hline Gemella sanguinis & Gram+ & facultative anaerobe & $\begin{array}{l}\text { periodontal pathogen; affects the periodontal health status and is prevalent in } \\
\text { refractory periodontitis; in subgingival niche }\end{array}$ & {$[5,37]$} \\
\hline Haemophilus parainfluenzae & Gram- & facultative anaerobe & significantly more prevalent in periodontal health than periodontitis & [37] \\
\hline Lactobacillus & Gram+ & anaerobe & $\begin{array}{l}\text { associated with carious lesions, anticaries potential, can inhibit tooth decay by } \\
\text { limiting growth and virulence properties of Streptococcus mutans", dominant } \\
\text { genera in the pulp chamber of apical periodontitis (rat model) }\end{array}$ & {$[45,48-50]$} \\
\hline Lautropia mirabilis & Gram- & facultative anaerobe & $\begin{array}{c}\text { localized on the back of the tongue, significantly more prevalent in periodontal } \\
\text { health than periodontitis }\end{array}$ & {$[37,51]$} \\
\hline Megaspahera elsdenii & Gram- & anaerobe & one of the most abundant genera in the native biofilm & \\
\hline Megaspaera stantonii & Gram- & anaerobe & one of the most abundant genera in the native biofilm & \\
\hline Neisseria & Gram- & aerobic & $\begin{array}{l}\text { often found resistant to antibiotics in periodontal patients undergoing therapy; } \\
\text { affect the oral health status; }\end{array}$ & {$[5,52]$} \\
\hline Neisseria mucosa & Gram- & aerobic & Found in gingival plaque, affect the periodontal health status & [53] \\
\hline Neisseria subflava & Gram- & aerobe & populates the tongue dorsum, affects the periodontal health status & [53] \\
\hline Porphyromonas gingivalis & Gram- & anaerobe & $\begin{array}{c}\text { member of the "red complex", involved in periodontitis, primary infections of } \\
\text { endodontal lesions, associated with peri-implantitis }\end{array}$ & {$[34,54]$} \\
\hline Prevotella denticola & Gram- & anaerobe & $\begin{array}{l}\text { dominant bacteria in oral lichen planus; abundance in the oral cavity can lead to } \\
\text { mucosal inflammation and oral lichen planus; associated with periodontitis. }\end{array}$ & {$[4,5,9,10,12,13,55]$} \\
\hline Prevotella melaninogenica & Gram- & anaerobe & commensal bacterium, member of normal human oral microbiota & [56] \\
\hline Rothia mucilaginosa & Gram+ & aerobe & $\begin{array}{l}\text { found on the tongue (up to } 6 \% \text { ), found at high abundance on oral leukoplakia, } \\
\text { significantly more prevalent in periodontal health than periodontitis, marker for } \\
\text { early childhood caries }\end{array}$ & {$[3,37,57]$} \\
\hline Schaalia odontolytica & Gram+ & anaerobe & associated with healthy microbiota & [46] \\
\hline $\begin{array}{l}\text { Selenomonas sp. oral } \\
\quad \text { taxon } 136\end{array}$ & Gram- & anaerobe & $\begin{array}{c}\text { periodontal pathogen, significantly prevalent in refractory periodontitis, in } \\
\text { subgingival niche }\end{array}$ & {$[37]$} \\
\hline
\end{tabular}


Table 1. Cont.

\begin{tabular}{|c|c|c|c|c|}
\hline Genus and Species & Gram Type & Growth Conditions & Clinical Relevance & References \\
\hline Staphylococcus schleiferi & Gram+ & facultative anaerobe & veterinary pathogen, but can also cause opportunistic infections in humans & [58] \\
\hline Streptococcus koreensis & Gram+ & facultative anaerobe & associated with subgingival dental plaque/periododitis lesion & [58] \\
\hline Streptococcus pneumoniae & Gram+ & facultative anaerobe & associated with periodontal health; associated with sinusitis & {$[60]$} \\
\hline Streptococcus salivarius & Gram+ & facultative anaerobe & $\begin{array}{l}\text { colonizes the tongue } \\
\text { associated with carious lesions }\end{array}$ & {$[45,49]$} \\
\hline Streptococcus sanguinis & Gram+ & facultative anaerobe & $\begin{array}{l}\text { "pioneer species", colonizes teeth fast; important for supragingival biofilm } \\
\text { formation; may suppress the generation of caries; antagonism between } S \text {. } \\
\text { sanguinis and S. mutans; associated with oral health }\end{array}$ & {$[37,61]$} \\
\hline Streptococcus thermophilus & Gram+ & facultative anaerobe & poor biofilm former & [32] \\
\hline Tannerella forsythia & Gram- & anaerobe & $\begin{array}{c}\text { member of the "red complex"; in subgingival niche; associated with periodontal } \\
\text { disease and peri-implantitis }\end{array}$ & {$[4,5,9,10,12,13,62]$} \\
\hline Veillonella & Gram- & anaerobe & $\begin{array}{l}\text { found on the tongue, the buccal mucosa, and in saliva, } \\
\text { interactions between Streptococcus species and Veillonella species in the early } \\
\text { stages of oral biofilm formation; associated with caries, consistently resistant to } \\
\text { antibiotics in periodontal patients undergoing therapy; presence in children may } \\
\text { predict the development of future caries, indication for poor oral health. }\end{array}$ & {$[1,3,8,52]$} \\
\hline Veillonella atypica & Gram- & anaerobe & $\begin{array}{l}\text { early colonizers in oral biofilm formation; periodontal pathogen } \\
\text { significantly prevalent in refractory periodontitis; subgingival }\end{array}$ & {$[37,52]$} \\
\hline Veillonella dispar & Gram- & anaerobe & early colonizers in oral biofilm formation & {$[52]$} \\
\hline Veillonella parvula & Gram- & anaerobe & $\begin{array}{l}\text { associated with severe early childhood caries and intraradicular infections } \\
\text { (abscess, apical root canals, and dentinal tubules); } \\
\text { early colonizers in oral biofilm formation }\end{array}$ & [52] \\
\hline
\end{tabular}




\section{Materials and Methods}

\subsection{Coating Preparation}

The sample substrates had a size of $15 \times 15 \mathrm{~mm}$. The polymer coatings were fabricated as previously reported [63-65], and as described in the experimental section. In short, the sample substrates (silicon wafer pieces with a size of $15 \times 15 \mathrm{~mm}$ that had been pretreated with the cross-linker benzophenone-3-(ethoxysilane)) [65] were spin-coated with solutions containing the different polymers and the cross-linker pentaerythritol-tetrakis(3-mercaptopropionat). The polymer coatings obtained were UV irradiated. This caused covalent attachment of the polymers to the substrate and simultaneous formation of a polymer network. The surface-attached polymer networks were then washed with different solvents to extract unbound polymer chains, and dried. The polymer coatings obtained (Figure 1) had an average thickness of $190 \mathrm{~nm}$ (PSB), $155 \mathrm{~nm}$ (PZI), and $180 \mathrm{~nm}$ (SMAMP), as determined by ellipsometry. The PSB samples obtained were stored until use, and SMAMP and PZI were treated with $\mathrm{HCl}$ to remove the $\mathrm{N}$-boc protective groups, rinsed and dried directly before use.
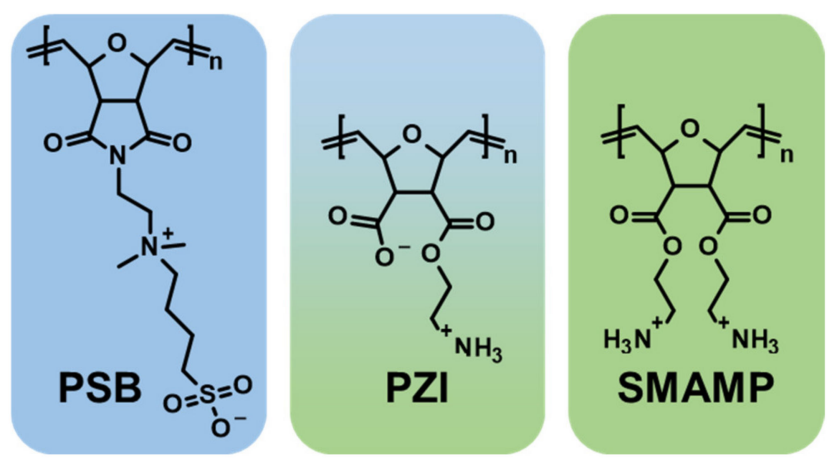

Figure 1. The effect of polymer coatings made from the protein-repellent PSB, the protein-repellent and antimicrobial PZI, and the mildly antimicrobial SMAMP on the growth and microbial composition of oral biofilms was studied.

PSB samples: First, a solution of pentaerythritol-tetrakis-(3-mercapto-propionat) $(0.1 \mathrm{~mL})$ in trifluoroethanol (TFE, $5 \mathrm{~mL}$ ) was prepared (solution A). PSB (30 mg) was dissolved in solution $\mathrm{A}(0.25 \mathrm{~mL})$, and TFE $(0.75 \mathrm{~mL})$ was added. The polymer was spincast onto pre-treated silicon wafers using the following parameters: $3000 \mathrm{rpm}, 500 \mathrm{rpm} \mathrm{s}^{-1}$, $20 \mathrm{~s}$. All wafers were irradiated with UV-light at a wavelength of $254 \mathrm{~nm}$ at $3 \mathrm{~J} \mathrm{~cm}^{-2}$ and extracted in TFE afterwards. The wafers were then rinsed with ethanol and dried in a stream of nitrogen.

SMAMP samples: First, a solution of pentaerythritol-tetrakis-(3-mercapto-propionat) $(0.1 \mathrm{~mL})$ in dichloromethane (DCM, $5 \mathrm{~mL}$ ) was prepared (solution B). SMAMP $(20 \mathrm{mg})$ was dissolved in solution $\mathrm{B}(0.25 \mathrm{~mL})$ and chloroform $(0.6 \mathrm{~mL})$ was added. The polymer was spin-cast onto pre-treated silicon wafers using the following parameters: $3000 \mathrm{rpm}$, $1000 \mathrm{rpm} \mathrm{s}^{-1}, 10 \mathrm{~s}$. All wafers were irradiated with UV-light at a wavelength of $254 \mathrm{~nm}$ at $3 \mathrm{~J} \mathrm{~cm}^{-2}$ and extracted in DCM afterwards. The wafers were then rinsed with ethanol and dried in a stream of nitrogen. At $24 \mathrm{~h}$ before intended use, the samples were immersed into $\mathrm{HCl}$ (4 M in dioxane) over night. Afterwards, they were then rinsed with ethanol and dried in a stream of nitrogen.

PZI samples: PZI (20 mg) was dissolved in water $(0.1 \mathrm{~mL})$ and methanol $(0.9 \mathrm{~mL})$. The polymer was spin-cast onto pre-treated silicon wafers using the following parameters: $3000 \mathrm{rpm}, 1000 \mathrm{rpm} \mathrm{s}^{-1}, 30 \mathrm{~s}$. All wafers were irradiated with UV-light at a wavelength of $254 \mathrm{~nm}$ at $0.3 \mathrm{~J} \mathrm{~cm}^{-2}$. The wafers were dipped into glacial acetic acid and dried in a stream of nitrogen. 


\subsection{Biofilm Growth}

Biofilm growth on the different materials was conducted as previously described [63], with slight modifications. The negative controls were uncoated silicon wafer pieces and the positive control was an uncoated silicon wafer piece treated with $0.2 \%$ chlorhexidine digluconate (CHX) solution for $24 \mathrm{~h}$. All samples were placed in a twelve-well cell culture plate (Greiner Bio-One, Frickenhausen, Germany) using sterilized tweezers. Stimulated human saliva from three healthy volunteers was taken after chewing paraffin tablets. All salivary samples were used freshly to avoid any additional modifications of the microbial composition of the inoculum. All saliva samples were vortexed for $30 \mathrm{sec}$, pooled and stored in $50 \mathrm{~mL}$ Falcon tubes (Greiner Bio-One, Frickenhausen, Germany). The exclusion criteria for the volunteers were severe systemic diseases, the use of antibiotics and antimicrobial mouthwashes within the last three months, pregnancy, and lactation. All volunteers gave their written consent. The study was approved by the ethics committee of the AlbertLudwigs-University Freiburg (381/15 and 91/15).

Each sample was inoculated with $1000 \mu \mathrm{L}$ of the pooled saliva. For initial microbial adhesion, all samples were incubated at $37^{\circ} \mathrm{C}, 95 \%$ humidity, and $5 \% \mathrm{CO}_{2}$ for $2 \mathrm{~h}$. After this initial phase of biofilm formation, $500 \mu \mathrm{L}$ of tryptic soy broth (TSB, Merck, Darmstadt, Germany) was added to each sample, followed by an incubation for $24 \mathrm{~h}$. After this second incubation time, $750 \mu \mathrm{L}$ of the culture in each well was discarded and fresh TSB were added to further incubate the sample for additional $24 \mathrm{~h}$, after which the culture medium was refreshed again. The samples were incubated under the same conditions for $24 \mathrm{~h}$. The biofilm formation took $72 \mathrm{~h}$ overall. Biofilm coated samples were each washed with $1000 \mu \mathrm{L}$ reduced transfer fluid (RTF) [66] to remove non-adherent bacteria. The biofilm was then carefully scraped from the surface and stored in RTF at $-80{ }^{\circ} \mathrm{C}$ until it was used for 16S-RNA sequencing. The microbial composition of total salivary bacteria, and that of the native biofilm formed on the uncoated silicon wafers, was also analyzed.

\subsection{RNA Isolation}

Biofilm samples were mixed 2:1 with lysis buffer comprising $5 \mathrm{mg} / \mathrm{mL}$ lysozyme (L6876 Sigma-Aldrich, Munich, Germany), $10 \mathrm{mg} / \mathrm{mL}$ proteinase K (3115836001, Roche Diagnostics, Mannheim, Germany), 9500 U/mL PNGase F (P0704, New England Biolabs, Frankfurt, Germany), 3000 U/mL RNAse Inhibitor (M0314, New England Biolabs, Frankfurt, Germany), 0.5\% NP40 (ab142227, Abcam, Cambridge, UK), $5 \mathrm{mM}$ Tris- $\mathrm{HCl}$ and 0.05 mM EDTA (TE pH 8 - 12090015, Thermo Fisher Scientific, Braunschweig, Germany). The total biofilm formed on each sample surface was used for the analysis. Quantification was performed by measuring the extractable total RNA, where $100 \mu \mathrm{L}$ lysis buffer was used to extract the total RNA. Samples were then incubated for $30 \mathrm{~min}$ at $37^{\circ} \mathrm{C}$, followed by a 30-min incubation at $55^{\circ} \mathrm{C}$. Immediately afterwards, total RNA was extracted using the Picopure RNA extraction kit (KIT0204, Thermo Fisher Scientific, Braunschweig, Germany) following the manufacturer's recommendations, including a DNAse incubation step as per the manufacturer's recommendations. The total RNA was eluted in $14 \mu \mathrm{L} \mathrm{H}_{2} \mathrm{O}$, and the RNA concentration was measured with a Qubit high sensitivity RNA kit (Q32852, Thermo Fisher Scientific, Braunschweig, Germany). Lysates were treated with DNAse and DNA content was measured with a Qubit ds High Sensitivity Assay kit in selected samples. In both, RNA and cDNA samples, no dsDNA was detectable.

\section{4. cDNA Synthesis and 16S Transcript Amplification}

cDNA was synthesized using the Superscript III kit (18080051, Thermo Fisher Scientific, Braunschweig, Germany) with $2 \mu \mathrm{M} 16 \mathrm{~S}$ gene-specific primer 1492R as per the manufacturer's recommendations [67]. For this, $8 \mu \mathrm{L}$ of isolated RNA was added to $1 \mu \mathrm{L}$ of gene specific primer and $1 \mu \mathrm{L}$ of $10 \mathrm{mM}$ dNTP mix. This mix was incubated at $65^{\circ} \mathrm{C}$ for 5 min before adding $10 \mu \mathrm{L}$ of cDNA Synthesis kit $(2 \mu \mathrm{L} 10 \times$ RT buffer, $4 \mu \mathrm{L} 25 \mathrm{mM}$ $\mathrm{MgCl} 2,2 \mu \mathrm{L} 0.1 \mathrm{M} \mathrm{DTT}, 1 \mu \mathrm{L}$ 40U/ $\mu \mathrm{L}$ RNAseOut and $1 \mu \mathrm{L}$ 200U/ $\mu \mathrm{L}$ SuperScript III RT) and incubating for $50 \mathrm{~min}$ at $50{ }^{\circ} \mathrm{C}$ followed by $5 \mathrm{~min}$ at $85^{\circ} \mathrm{C}$. 
A total of $10 \mu \mathrm{L}$ of cDNA was then further amplified using $1.25 \mu \mathrm{L}$ of $10 \mu \mathrm{M}$ each of the same gene-specific primers $27 \mathrm{~F}$ and $1492 \mathrm{R}$ with $12.5 \mu \mathrm{L}$ of Q5 High fidelity PCR master mix (M0492, New England Biolabs, Frankfurt, Germany). PCR was performed for $30 \mathrm{~s}$ at $98{ }^{\circ} \mathrm{C}$ followed by 35 cycles of $10 \mathrm{~s}$ at $98^{\circ} \mathrm{C}, 30 \mathrm{~s}$ at $63{ }^{\circ} \mathrm{C}$, and $30 \mathrm{~s}$ at $72{ }^{\circ} \mathrm{C}$. A final extension of $2 \mathrm{~min}$ at $72{ }^{\circ} \mathrm{C}$ was performed. The PCR product was purified by means of a 1:1 incubation with Ampure XP beads (A63881, Beckman Coulter Biomedical, Munich, Germany) as per the manufacturer's instructions. Two no RNA samples were run in parallel for cDNA synthesis and PCR and yielded no detectable PCR product as a control for potential contamination during sample preparation.

\subsection{Sequencing Library Preparation and MinION Sequencing}

Multiplexed sequencing libraries were prepared using the Ligation Sequencing Kit (SQK-LSK109, Oxford Nanopore Technologies (ONT), Oxford, UK) in conjunction with the native barcoding expansion kit ((EXP-NBD104, ONT), Oxford, UK) as per protocols provided by the manufacturer. In short, 50-60 fmol of PCR product were end repaired and dA-tailed using the NEBNext Ultra II End repair / dA-tailing Module (E7546, New England Biolabs [NEB], Frankfurt, Germany) by incubating $24 \mu \mathrm{L}$ of PCR product in water with $1.75 \mu \mathrm{L}$ Ultra II End-prep reaction buffer and $1.5 \mu \mathrm{L}$ Ultra II End-prep enzyme mix at $20{ }^{\circ} \mathrm{C}$ for $10 \mathrm{~min}$ followed by incubation at $65^{\circ} \mathrm{C}$ for $5 \mathrm{~min}$. End repaired PCR product was isolated using $30 \mu \mathrm{L}$ Ampure XP beads (A63881, Beckman Coulter, Krefeld, Germany) and resuspended in $11.5 \mu \mathrm{L}$ water.

A total of $11.25 \mu \mathrm{L}$ of end-repaired purified PCR product was then barcoded by incubation with $1.25 \mu \mathrm{L}$ of native barcode and $12.5 \mu \mathrm{L}$ of NEB Blunt/TA Ligase Master Mix (M0367, NEB) for $10 \mathrm{~min}$ at room temperature. Barcoded samples were subsequently purified with $25 \mu \mathrm{L}$ Ampure XP beads and resuspended in $12 \mu \mathrm{L}$ water. The barcoded sample concentration was measured using the Qubit dsDNA HS kit (Q32851, Thermo Fisher Scientific, Braunschweig, Germany).

Equimolar amounts of barcoded samples were pooled to yield 100-120 fmol of pooled barcoded samples in a total volume of $65 \mu \mathrm{L}$. Each pool was then incubated with $5 \mu \mathrm{L}$ Adapter Mix II, $20 \mu \mathrm{L}$ NEBNext Quick Ligation Reaction Buffer (B6058, NEB) and $10 \mu \mathrm{L}$ Quick T4 DNA Ligase (E6057, NEB) for $10 \mathrm{~min}$ at room temperature. Adapter ligated sample pools were purified using $50 \mu \mathrm{L}$ of Ampure XP beads and two washes with $250 \mu \mathrm{L}$ of Short Fragment Buffer prior to being resuspended in $15 \mu \mathrm{L}$ of Elution Buffer.

Sample pools were quantified using the Qubit dsDNA HS kit and stored at $4{ }^{\circ} \mathrm{C}$ until sequencing was performed. For each sequencing run, 10 to $15 \mathrm{fmol}$ of sequencing library were used, with flow cell preparation and sample loading performed according to manufacturer's protocol.

In total, four to five replicates of uncoated PSB, SMAMP, and PZI coated surfaces were sequenced alongside one $\mathrm{CHX}$ treated uncoated sample and two sputum samples to test for initial bacterial content prior to biofilm growth. For each sequencing library, twelve biofilm samples were combined in a randomized fashion to reduce batch effects due to library preparation and sequencing-induced technical variation. Sequencing libraries were sequenced on a MinION R9 flow cell for 18-24 h following the manufacturer's recommendations.

\subsection{Data Analysis}

Fast5 files obtained from the sequencing runs were base-called and demultiplexed using a high accuracy base-calling mode with standard settings with the GPU-based guppy software (ONT, Oxford, UK) version 4.2.2). Base-called fastq files were then further processed to identify bacterial populations using the centrifuge software version 1.0.4beta in conjunction with a precompiled index for 'bacteria, archea, viruses, human' version $12 / 06 / 2016$ as provided by the centrifuge package providers [68]. Visualization and data analysis of the centrifuge output was performed using basic $R$ functions [69] as well as $R$ packages ggplot2 and pavian ( $\mathrm{R}$ package version 1.2.0, https:/ / github.com/fbreitwieser/ 
pavian, accessed on 11 March 2021) [70,71]. Relative abundance was calculated on the basis of the total amount of sequences obtained per sample. Species or genera constituting less than $1 \%$ in any sample were excluded from analysis.

Alpha and beta diversity measures were calculated using the $R$ package vegan (Community Ecology Package, R package version 2.5-7., https://CRAN.R-project.org/package= vegan, published by J. Oksanen, F. Guillaume Blanchet, Michael Friendly, Roeland Kindt, Pierre Legendre, Dan McGlinn, Peter R. Minchin, R. B. O'Hara, Gavin L. Simpson, Peter Solymos, M. Henry H. Stevens, Eduard Szoecs, and Helene Wagner 2020, accessed on 11 March 2021) and visualized using the ggplot and pheatmap packages (Raivo Kolde 2019: $\mathrm{R}$ package version 1.0.12. https: / /CRAN.R-project.org/package=pheatmap, access on 11 March 2021).

\section{Results}

Three poly(oxanorbornene)-based polymer coatings with different bioactivity profiles were chosen for this study to evaluate their effects on the microbial composition of biofilms formed by total human salivary bacteria. The poly(oxanorbornene)-based poly(sulfobetaine) (PSB) is protein-repellent but not antimicrobially active [63,64,72]. The polycationic (SMAMP) is intrinsically active against bacteria, albeit only mildly, with about $90 \%$ growth reduction of Escherichia coli and Staphylococcus aureus bacteria after two hours of incubation [65]. The third coating is a poly(carboxyzwitterion) (PZI) with charge-switchable properties [63,64]. It is protein-repellent under physiological conditions, but becomes intrinsically antimicrobial in the presence of bacteria, presumably because they secrete acidic metabolites $[63,64]$. The polymer coatings obtained were very smooth and fully covered the substrate, as evaluated by atomic force microscopy. Due to the low thickness of the coating, which was below $200 \mathrm{~nm}$ in all cases, the macroscopic mechanical properties of the substrate were not altered. All coatings were non-toxic to human keratinocytes, as determined by the AlamerBlue assay. Full details of the physical-chemical characteristics and the bioactivity of these coatings, including their compatibility with human cells, can be found in the references given above. To assess the effect of these different bioactivity profiles on biofilm microbiota, they were incubated with unstimulated human saliva for biofilm film formation by the salivary bacteria. After $72 \mathrm{~h}$, the biofilms were harvested and analyzed by means of 16S RNA sequencing.

The biofilm formed on the different samples was exemplarily verified by confocal laser scanning microscopy and live/dead staining. Example images have now been added in the Supplementary Materials (Figure S1).

\subsection{Total Amount of Biofilm RNA}

The total amount of extracted RNA was also determined, as a measure of the amount of living bacteria in the biofilm. As shown in Figure 2, this amount significantly varied by surface coating type (see also Table S1 in the supporting information). SMAMP coatings reduced the amount of extractable RNA by about $40 \%$ when compared to uncoated surfaces (NegCtrl in Figure 2); PZI and PSB-coated surfaces even had 90\% less extractable RNA (Figure 2). No significant differences could be seen between PZI and PSB-coated surfaces regarding total extractable RNA. 

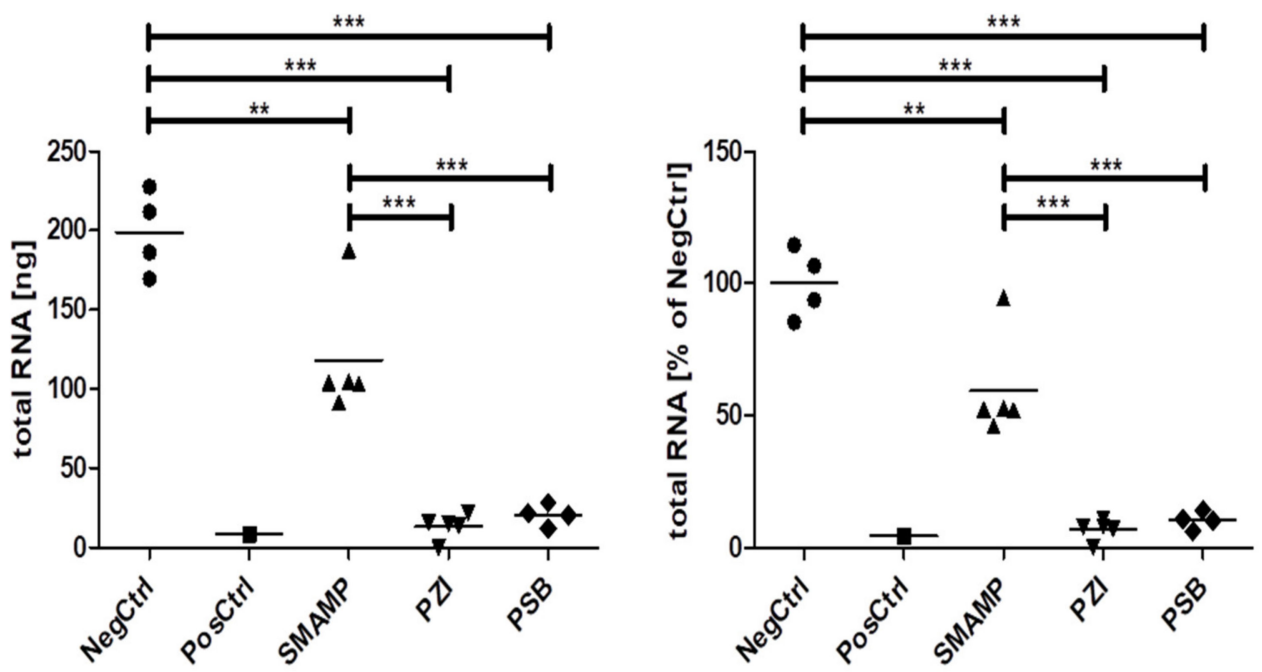

Figure 2. Total extractable RNA in the harvested biofilms as a percentage of the mean of the negative control (NegCtrl = uncoated silicon wafer, PosCtrl = uncoated silicon wafer with additional CHX). Stars depict significant differences as determined by one-way ANOVA with Tukey's post-hoc test. ${ }^{* *} p<0.01,{ }^{* * *} p<0.001$.

\subsection{Microbial Composition of Human Saliva and Biofilm Composition on All Surfaces}

The bacterial composition of the biofilms was then analyzed for each biofilm sample, except for one PZI sample, which yielded no detectable RNA after isolation, by sequencing of the $16 \mathrm{~S}$ ribosomal RNA molecule which allows identifying individual bacterial species within a complex mixture. The results are reported as the top 20 species and genera for each sample type in counts per million (CPM) and percent (Figures 3-6, and Tables S2-S5 in the Supporting Information). Due to the number of processing steps required, and the method accuracy, bacteria present in quantities below $1 \%$ relative abundance were not considered for further analysis. The 20 most abundant bacterial genera thus identified are presented in Figure 3 and the 20 most abundant bacterial species identified in these samples are presented in Figure 4 for (a) bacteria found in saliva, (b) bacteria harvested from biofilms grown on uncoated substrates (called native biofilms in the following), and (c) bacteria harvested from biofilms grown on uncoated substrates to which the disinfectant chlorhexidine digluconate ( $\mathrm{CHX}$ ) had been added. These numbers have also been converted into their relative abundance in the biofilm (in percent, Tables S2-S5). It should be kept in mind that the amount of $16 \mathrm{~S}$ rRNA also correlates to a high number of ribosomes, which in turn correlates with the activity of bacteria, since active bacterial cells contain a higher number of ribosomes than inactive ones. 
a)

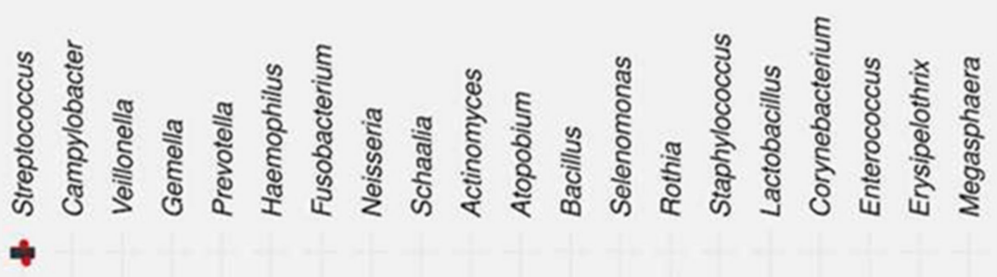

$\sum_{0}^{2 e+05}$ 占官

$0 \mathrm{e}+00$

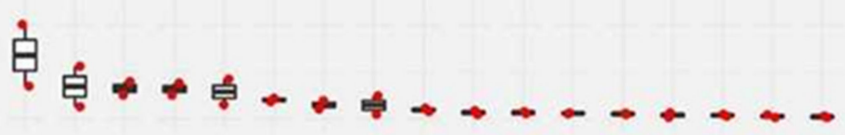

b)

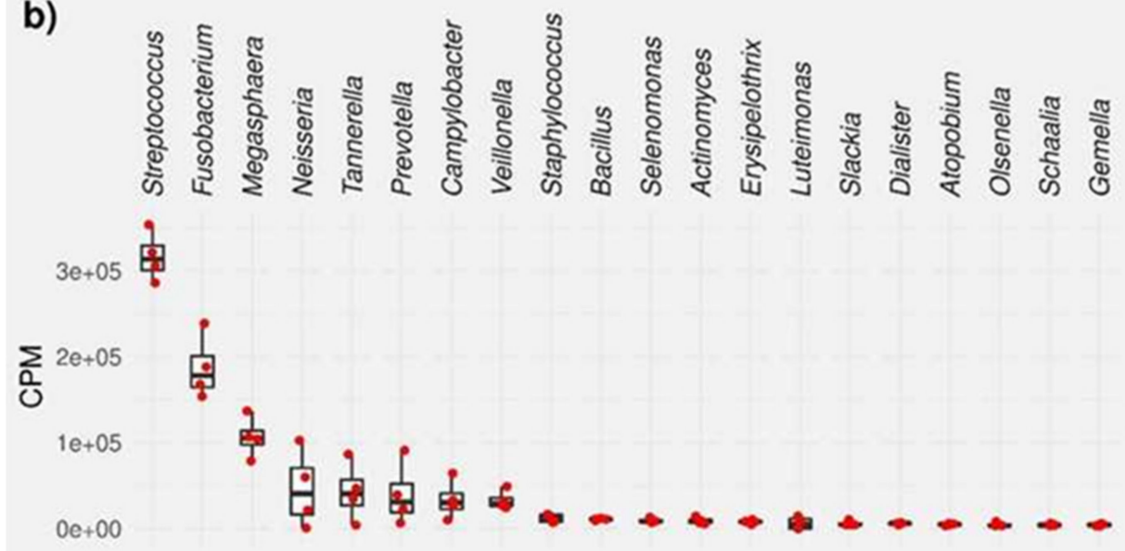

c)

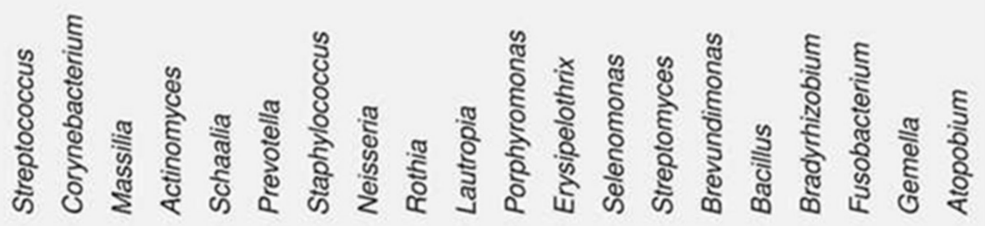

$2 e+05$

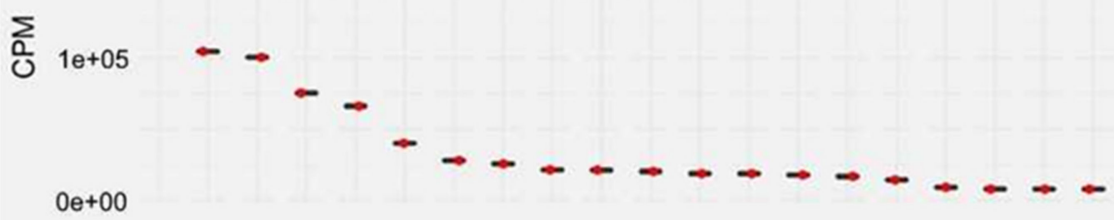

Figure 3. Top 20 most abundant bacterial genera, presented as CPM, for (a) bacteria found in saliva, (b) bacteria harvested from native biofilms grown on uncoated substrates, and (c) bacteria harvested from biofilms grown on uncoated substrates to which the disinfectant chlorhexidine digluconate (CHX) had been added. 


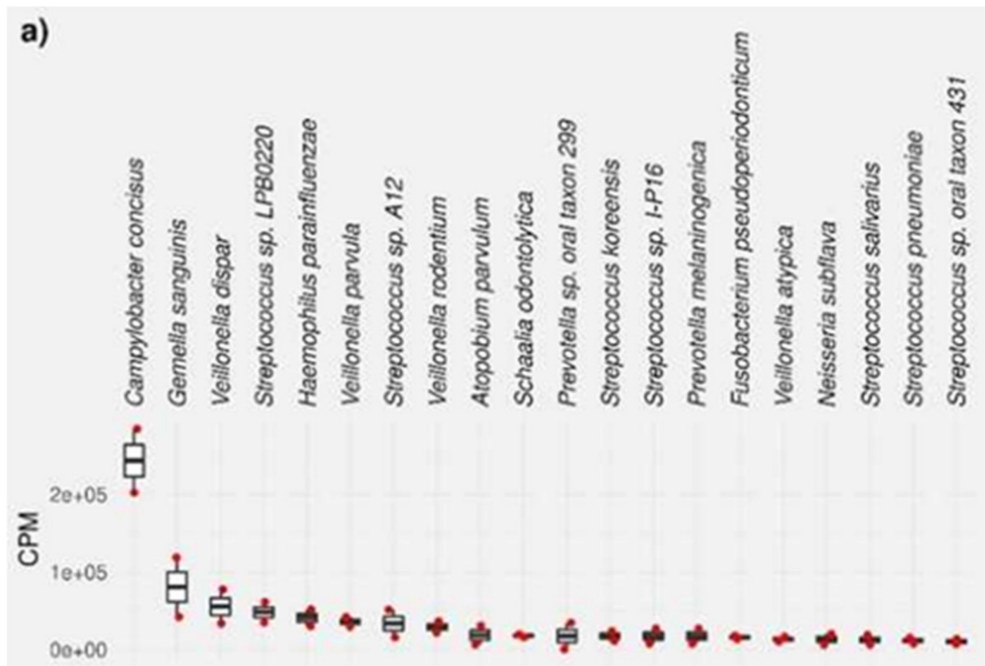

b)
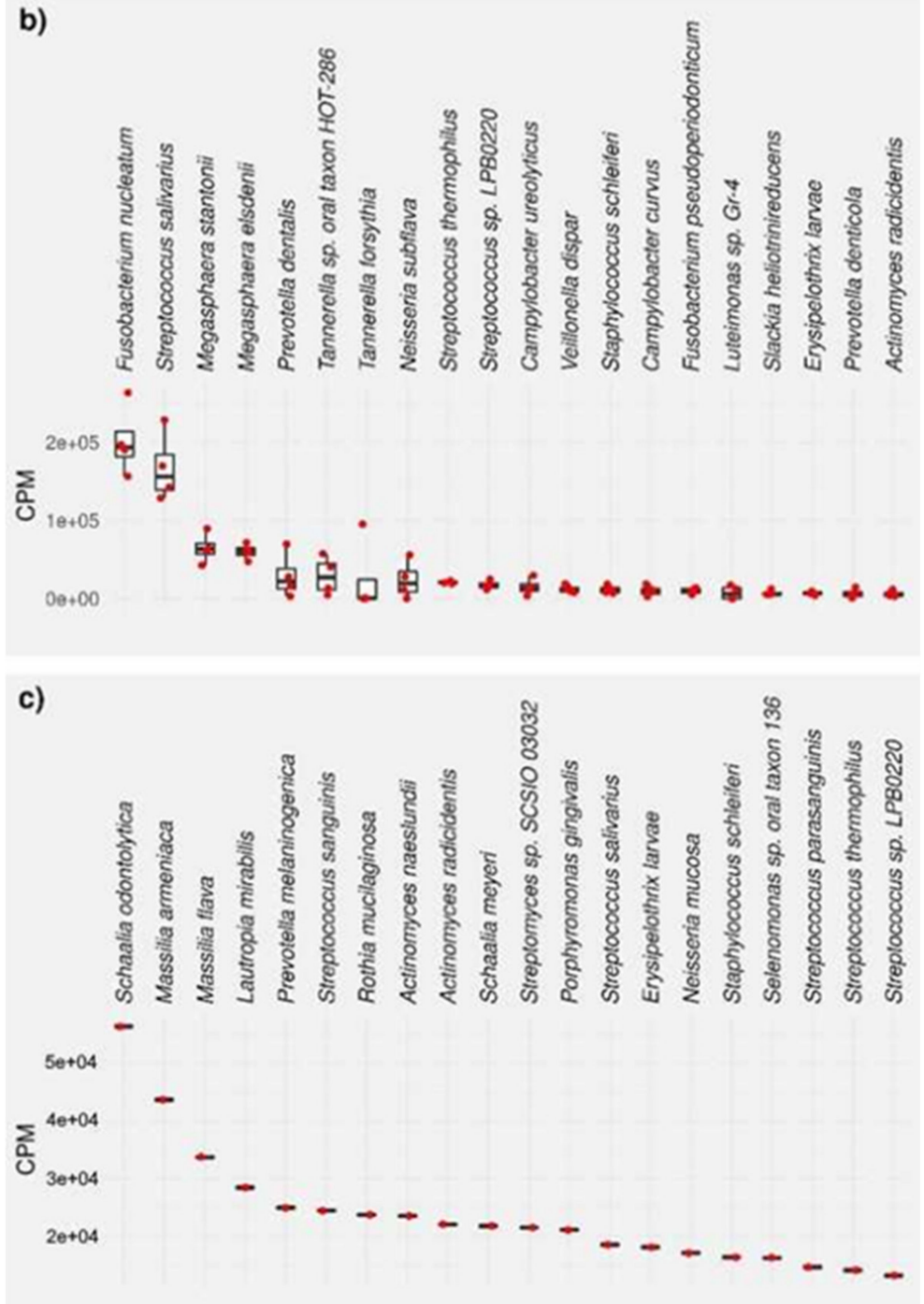

Figure 4. Top 20 most abundant bacterial species, presented as CPM, for (a) bacteria found in saliva, (b) bacteria harvested from native biofilms grown on uncoated substrates, and (c) bacteria harvested from biofilms grown on uncoated substrates to which the disinfectant chlorhexidine digluconate (CHX) had been added. 


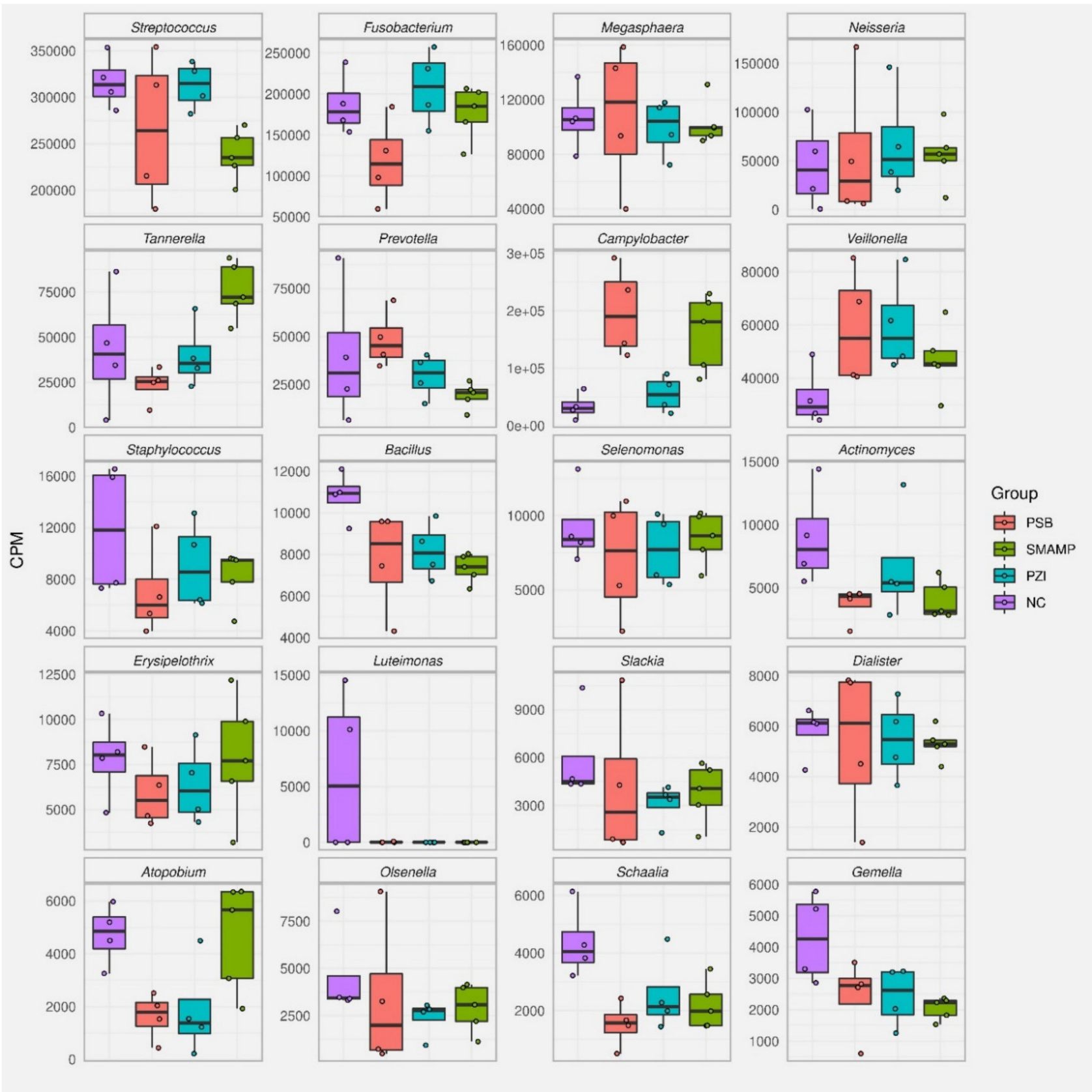

Figure 5. Top 20 most abundant bacterial genera, presented as CPM, for bacteria harvested from native biofilms grown on uncoated substrates (NC, purple), and bacteria harvested from biofilms grown on polymer-coated substrates (PSB, red; PZI, turquois; SMAMP, green). 


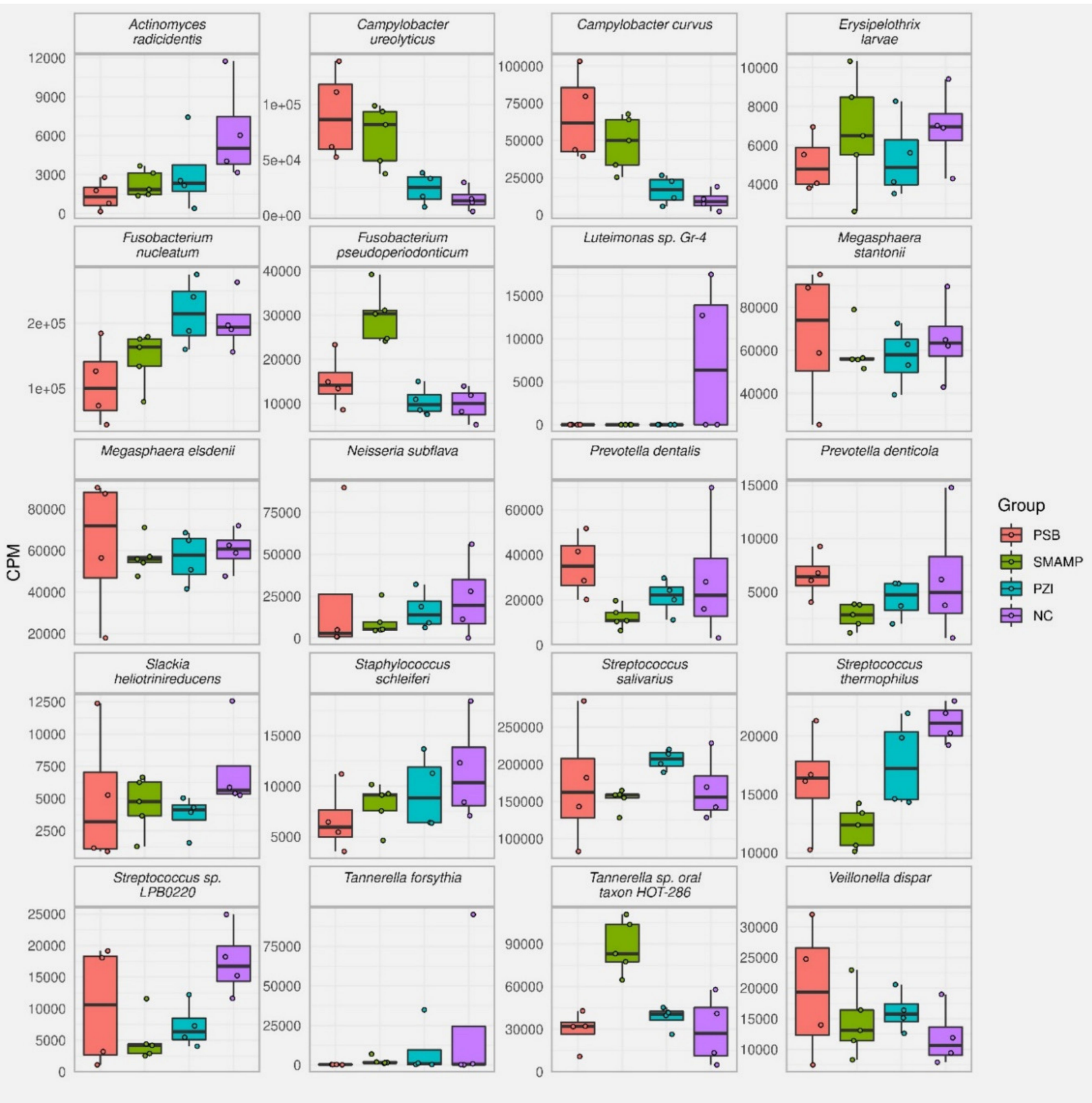

Figure 6. Top 20 most abundant bacterial species, presented as CPM, for bacteria harvested from native biofilms grown on uncoated substrates (NC, purple), and bacteria harvested from biofilms grown on polymer-coated substrates (PSB, red; PZI, turquois; SMAMP, green).

In both saliva and the native biofilm, Streptococci were the most abundant bacteria, with a relative abundance of $31.2 \%$ and $35.6 \%$, respectively, in line with their importance in oral biofilm formation. Four of the five following most abundant genera in saliva (Campylobacter, Veillonella, Gemella, and Haemophilus) had a drastically diminished abundance in the native biofilm compared to saliva. The counts of Campylobacter spp. and Veillonella spp. were reduced by one order of magnitude (from $31.2 \%$ to $3.8 \%$, and from $17.2 \%$ to $3.7 \%$, respectively), while Gemella spp. (from $7.1 \%$ to $0.5 \%$ ) and Haemophilus spp. (from $3.4 \%$ to $<0.5 \%$ ) became insignificant in the formed biofilm. The relative abundance of Prevotella spp.- - the fifth most abundant genus in saliva-and Neisseria spp. (ranked seventh) was more or less unchanged in the native biofilm (from $3.6 \%$ to $4.5 \%$, and from $3.0 \%$ to $5.2 \%$, respectively). Interestingly, Fusobacterium spp.- which only had an abundance of 3.3\% 
in saliva - had a share of $21.0 \%$ in the native biofilm, thus taking the second rank after Streptococcus spp. Moreover, genera like Megasphaera and Tannerella, which held little to no importance in the saliva sample, increased their relative abundance from $0.2 \%$ to $12 \%$, and from $<0.2 \%$ to $4.8 \%$ in native biofilm. The slightly higher relative abundance of Staphylococcus spp. and Bacillus spp. in the biofilm compared to their abundance in saliva (from $0.6 \%$ to $1.3 \%$, and from $1.0 \%$ to $1.2 \%$ ) might hold relevance due to their pathogenic potential.

The analysis of alpha-diversity (Figure S2) showed a significant increase of species richness (increase of alpha-diversity) on samples coated with SMAMP as compared with the negative control (uncoated samples) $(p=0.013)$. The species richness also increased significantly on the SMAMP surface in comparison to the samples coated with PZI ( $p=0.017)$. The beta-diversity (Figure S3) was analyzed in order assess differences between the microbial communities on the differently coated surfaces and the negative control. The beta-diversity revealed significant differences between the SMAMP surface and the negative control $(p=0.014)$. Significant differences of the microbial composition were also revealed by the beta-diversity between and the PZI and SMAMP surface $(p=0.01)$.

In the biofilm grown in the presence of $\mathbf{C H X}$, Streptococcus was still the most abundant genus (with 25.2\%), and other genera that were insignificant in both saliva and the native biofilm had a large share in the CHX-treated biofilm (Corynebacterium, 12.6\%; Massilia, 12.1\%; Actinomyces, 9.1\%; and Schaalia, 8.0\%). Prevotella, Staphylococcus, and Neisseria were found in similar amounts in these samples as in saliva and the native biofilm.

The 20 most abundant bacterial species identified in these samples are presented in Figure 4 for (a) bacteria found in saliva, (b) bacteria harvested from native biofilms grown on uncoated substrates, and (c) bacteria harvested from biofilms grown on uncoated substrates to which the disinfectant CHX had been added. In the analysis by species, more differentiated data is obtained. In particular, some of the species that have a dominant role in saliva do not even appear among the top 20 most abundant bacteria of the native biofilm, while another species from the same genus have a higher abundance in the biofilm than in saliva. For example, the most abundant species in saliva was Campylobacter concisus (32.3\%), which is also the only bacterium of this genus in the top 20 most abundant species list in saliva. Nonetheless, C. concisus does not appear in the untreated biofilm, while C. ureolyticus and C. curvus have an abundance of $2.0 \%$ and $1.3 \%$, respectively. The second most abundant species in saliva, Gemella sanguinis, has an abundance of $10.7 \%$ in that sample, although does not appear in the native biofilm. Third in line is Veillonella dispar, with $7.4 \%$ in saliva, and $1.6 \%$ in the biofilm. Other Veillonella spp. can be found further down the list in saliva: V. parvula, V. rodentium, and V. atypica, but not in the native biofilm. Streptococcus sp. LPB0220 is the fourth most abundant species found in saliva, with other Streptococci following in positions $7,12,13,18,19$, and 20. Out of these, Streptococcus salivarius has the second rank in the top 20 list in the native biofilm, with a relative abundance of $22.9 \%$, while other Streptococci (S. thermophilus, 2.9\%; S. sp. LPB0220, 2.4\%) follow at rank 9 and 10. Haemophilus parainfluenzae (rank 5, 5.5\%), Atopobium parvulum (rank 9, 3.9\%), and Schaalia odontolytica (rank 10, 2.4\%) and complete the list of the top 10 species in saliva, yet none of them appear in the top 20 list in saliva.

Overall, the native biofilm has a completely different composition of bacterial species, with Fusobacterium nucleatum (rank 1, 27.6\%) and the aforementioned Streptococcus salivarius accounting for half of the present bacteria. Megasphaera stantonii (rank 3, 8.9\%) and Megasphaera elsdenii (rank 4, 8.2) follow in relative abundance. It is interesting to note that there is no such dominance of a few species in the CHX-treated biofilm, where Schaalia odontolytica (rank 1, 11.9\%), Massilia armeniaca (rank 2, 9.2\%) and Massilia flava (rank 3, 7.1\%) are followed by species from different genera at low single-digit percentages. Out of the top three, only Schaalia odontolytica is found in the top 20 saliva list (rank 10, 2.4\%), and none in the native biofilm.

The 20 most abundant genera and species found in biofilms grown on the polymercoated substrates PSB, PZI, and SMAMP are found in Tables S4 and S5 in the Supporting Information. The most useful way to compare these data with the 20 most abundant genera 
and species found in the native biofilms was to plot their abundance in CPM side by side (Figures 5 and 6).

Thus, the top 20 most abundant bacterial genera of bacteria harvested from the native biofilms and biofilms grown on polymer-coated the substrates PSB, PZI, and SMAMP are compared in Figure 5. As described above, Streptococcus spp., Fusobacterium spp., and Megasphera spp. are the most abundant bacteria in the native biofilm, followed by Neisseria spp., Tannerella spp., Prevoltella spp., Campylobacter spp., and Veillonella spp. On PSB-coated substrates, these genera also make up the top nine of the list, only in different proportions. Most notably, the share of Fusobacterium spp. is reduced from $21.0 \%$ to $12.5 \%$, while that of Campylobacter spp. increased from 3.8\% to $21.1 \%$. The relative abundance of the other top nine genera is quite similar. When comparing the top 20 species list of the native and the PSB-grown biofilm (Figure 6 and Table 2), it is found that they have a total of fourteen species in common. Fusobacterium nucleatum (rank 2, 13.5\%) and Streptococcus salivarius (rank 1, 22.8\%) were also the most abundant species on PSB, although the abundance of F. nucleatum (associated with poor oral health) is strongly reduced compared to the native biofilm. Instead, Campylobacter ureolyticus takes a share of $11.5 \%$ on PSB (up from $2 \%$ ), Campylobacter curvus is found with $8.4 \%$ abundance (up from 1.3\%), and Campylobacter gracilis, which does not appear on the list of the native biofilm, has a share of $3.2 \%$ on PSB.

Table 2. Relative abundance of bacteria (in percent), found in the native biofilm, and the biofilms formed on PSB-, PZI-, and SMAMP-coated substrates, listed by species. Standard deviations of the data are found in Tables S2-S5 in the Supporting Information.

\begin{tabular}{|c|c|c|c|c|}
\hline Species & Native & PSB & PZI & SMAMP \\
\hline Fusobacterium nucleatum & 27.6 & 13.5 & 27.3 & 18.0 \\
\hline Streptococcus salivarius & 22.9 & 21.8 & 26.1 & 18.8 \\
\hline Megasphaera stantonii & 8.9 & 8.4 & 7.2 & 7.3 \\
\hline Megasphaera elsdenii & 8.2 & 7.9 & 7.2 & 7.0 \\
\hline Prevotella dentalis & 4.0 & 4.5 & 2.7 & 1.5 \\
\hline Tannerella sp. oral taxon HOT-286 & 4.0 & 3.7 & 4.8 & 10.8 \\
\hline Tannerella forsythia & 3.3 & n.d. & 1.2 & n.d. \\
\hline Neisseria subflava & 3.3 & 3.0 & 2.1 & 1.2 \\
\hline Streptococcus thermophilus & 2.9 & 2.0 & 2.2 & 1.5 \\
\hline Streptococcus sp. LPB0220 & 2.4 & 1.3 & 0.9 & n.d. \\
\hline Campylobacter ureolyticus & 2.0 & 11.5 & 3.1 & 8.9 \\
\hline Veillonella dispar & 1.6 & 2.5 & 2.0 & n.d. \\
\hline Staphylococcus schleiferi & 1.6 & 0.8 & 1.2 & 1.0 \\
\hline Campylobacter curvus & 1.3 & 8.4 & 2.1 & 5.9 \\
\hline Fusobacterium pseudoperiodonticum & 1.3 & 1.9 & 1.3 & 3.7 \\
\hline Luteimonas sp. Gr-4 & 1.0 & n.d. & n.d. & n.d. \\
\hline Slackia heliotrinireducens & 1.0 & n.d. & n.d. & n.d. \\
\hline Erysipelothrix larvae & 0.9 & n.d. & n.d. & n.d. \\
\hline Prevotella denticola & 0.9 & n.d. & n.d. & n.d. \\
\hline Actinomyces radicidentis & 0.9 & n.d. & n.d. & n.d. \\
\hline Neisseria mucosa & n.d. & 1.5 & 3.8 & 3.7 \\
\hline Veillonella parvula & n.d. & 1.4 & 1.7 & 1.1 \\
\hline Veillonella rodentium & n.d. & 1.2 & 1.4 & 0.9 \\
\hline Porphyromonas gingivalis & n.d. & n.d. & 1.0 & n.d. \\
\hline Streptococcus gordonii & n.d. & n.d. & 0.7 & n.d. \\
\hline Campylobacter gracilis & n.d. & 3.2 & n.d. & 3.0 \\
\hline Streptococcus parasanguinis & n.d. & n.d. & n.d. & 2.3 \\
\hline Erysipelothrix larvae & n.d. & n.d. & n.d. & 0.8 \\
\hline Lachnoanaerobaculum umeaense & n.d. & n.d. & n.d. & 0.8 \\
\hline Prevotella denticola & n.d. & 0.8 & n.d. & n.d. \\
\hline Campylobacter concisus & n.d. & 0.8 & n.d. & n.d. \\
\hline
\end{tabular}

When comparing the microbial composition of the biofilm on the SMAMP-coated substrates and on the PSB-coated ones, similar genera are found at the top of the relative 
abundance list: Streptococcus, Fusobacterium, Campylobacter, and Megasphaera are the four most abundant genera, followed by Veillonella, Neisseria, Prevotella, and Tannerella. The most striking quantitative differences of PSB- and SMAMP-coated substrates are the significantly higher abundance of Fusobacterium spp. on SMAMP (18.8\%, compared to $12.5 \%$ on PSB, and $21 \%$ in the native biofilm). In this respect, the biofilm grown on SMAMP is in between the bacteria distribution of PSB and the uncoated substrate: it has a high amount of Fusobacterium spp., like the uncoated substrate, but also a substantial amount of Campylobacter spp. Another notable feature of the SMAMP-grown biofilm is a significantly higher amount of Tannerella spp. (8\%, up from $2.5 \%$ on PSB). Compared to the native biofilm, SMAMP-grown biofilms also have a lower amount of Streptococcus spp., and possibly Staphylococcus spp. (large error bars), Bacillus spp., and Actinomyces spp., but a higher amount of Tannerella spp., Campylobacter spp., and Veillonella spp.

At the species level (Figure 6, Table 2), it was found that the top 20 list of SMAMPgrown and PSB-grown biofilms have seventeen species in common, and most of them in a similar amount. On SMAMP, S. salivarius and F. nucleatum are still the most abundant species, although at a more equal proportion to each other than on PSB. Moreover, the relative amounts of $M$. stantonii, M. elsdenii, C. ureolyticus, and C. curvus are at a similar level for both types of coatings. However, Tannerella sp. oral taxon HOT-286 ranks in third position in the SMAMP-grown biofilm, with 10.8\% relative abundance. In the direct comparison of the native biofilm and the biofilm grown on SMAMP, a significant reduction of Acinomyces radicidentis, F. nucleatum, S. thermophilus, and Streptococcus sp. LPB02 20 is observed on SMAMP, while the amounts of C. ureolyticus, C. curvus, Fusobacterium pseudoperiodonticum, and Tanerella sp. oral taxon HOT-286 are significantly increased.

The biofilm grown on PZI-coated surfaces appears more similar to the native biofilm on the genera level than the other coated substrates (Figure 5). Both the order of abundance of the top four genera are the same in both samples, and their relative amounts are similar. The other top twelve genera follow in a slightly different order yet with still comparable amounts, except for Veillonella, which increases from $3.7 \%$ in the native biofilm to $6.4 \%$ on the PZI-grown biofilm. At the species level, this finding is confirmed, with F. nucleatum, S. salivarius, M. stantonii, and M. elsdenii found as the top four species and at comparable relative abundance in PZI-grown and native biofilms (Table 2, Figure 6). Other species that have similar levels in both sample types are F. pseudoperiodonticum, N. subflavia, Prevotella dentalis, C. ureolyticus, C. curvus, and others. Notably, PZI-grown biofilms contain 3.8\% of Neisseria mucosa, $1.7 \%$ of Veillonella parvula, and $1.4 \%$ Veillonella rodentium, which are all not among the top 20 species in the native biofilm. However, all three species appear in the biofilms grown on PSB and SMAMP, and both Veillonella spp. were present in significant amounts in saliva.

\section{Discussion}

Three poly(oxanorbornene)-based polymer coatings with different bioactivity profile were chosen for this study to evaluate their effects on the microbial composition of biofilms formed by total human salivary bacteria: The poly(oxanorbornene)-based poly(sulfobetaine) (PSB), the polycationic (SMAMP) and the third coating is a poly(carboxyzwitterion) (PZI). After $72 \mathrm{~h}$, the biofilms were harvested and analyzed by 16S RNA sequencing.

Using total salivary bacteria to evaluate the biofilm formation on different material surface has been shown to be a meaningful model, since new materials cannot be tested in vivo within the oral cavity and since oral human salivary microbiota has a high diversity, which reflects a worst case of biomaterial-associated infections [73]. The bacterial biofilm composition was analyzed by sequencing the $16 \mathrm{~S}$ ribosomal RNA as previously published [74], using full length sequencing of the 16S rRNA gene with nanopore sequencing, which allows for very sensitive differentiation of bacterial composition in the analyzed samples. Synthesis of cDNA and hence 16S rRNA sequencing was chosen over $16 \mathrm{~S}$ rDNA sequencing as this approach is better suited for evaluating samples of living 
bacteria [74]. Using this technique is meaningful to evaluate the effects of polymer coatings on adherent bacteria.

With exception of Bacillus spp. and Staphylococcus spp., all of these abundant bacteria have been described in the in-situ oral biofilm $[1,5,19]$. In a state of oral health, there is an equilibrium of these different bacteria in the oral cavity [14]. Deviations of this equilibrium have been associated with various oral diseases. For example, a high abundance of Fusobacterium spp., Tannerella spp., Prevotella spp., and Campylobacter spp. have been associated with poor periodontal oral health or peri-implantitis $[5,12,13,75]$. An increase of the abundance of Streptococcus spp. and Veillonella spp. is also an indication of poor oral health regarding caries development $[1,8]$. The detection of Staphylococcus spp. and Bacillus spp. in the native biofilm may be related to food consumption, since foodborne bacteria such as Enterococcus spp. have been shown to be able to integrate in oral biofilms in situ [76]. However, it has been shown that Staphylococcus aureus and Staphylococcus epidermidis can be associated with peri-implantitis of titanium oral implants [77,78].

In the biofilm grown in the presence of $\mathbf{C H X}$, the amount of recovered bacterial RNA was overall more than one order of magnitude lower than in the native biofilm, thus confirming the well-document activity of $\mathbf{C H X}$ against bacteria $[79,80]$. Among the bacteria detected in the biofilm grown in the presence of CHX, Schaalia spp. have been isolated from tongue biofilms [81], whereas Massilia spp. are a non-oral bacteria that have been isolated from environment (air and soil), tobacco and the blood of an immunocompromised patient, as well as from an otitis media infections [82,83]. Since there is evidence that bacteria may develop resistance towards chlorhexidine digluconate [84], it cannot be excluded that members of these taxa are less sensitive towards $\mathbf{C H X}$ and hence overgrew other typical oral biofilm bacteria.

The results from the total extractable RNA are in strong agreement with previous results of protein adhesion studies on the polymer-coated substrates [63,64]. PSB and PZI-which are known to be protein-repellent-also reduced the amount of extractable RNA (and thus the number of living bacteria) by $90 \%$, compared to the uncoated substrate. While PZI has an additional intrinsic antimicrobial activity, PSB does not, whereby this reduction seems to be an effect of reduced bacterial adhesion on the surface, rather than an effect of antimicrobial activity. On the other hand, SMAMP is mildly antimicrobial and polycationic, and thus protein-adhesive [63-65]. Consequently, its reduction of the extractable RNA is only $40 \%$. This indicates that bacteria can adhere on this surface, but some of the adhering bacteria are killed, so that the overall amount able to initiate biofilm formation is reduced. When comparing the native biofilm to all three coating types, it was found that SMAMP caused a higher relative abundance of Campylobacter spp., F. pseudoperiodonticum and Tanerella sp. oral taxon HOT-286), while other bacteria were diminished (e.g., two each of the Streptococcus spp. and Prevotella spp.). Importantly, the SMAMP coating also significantly reduced the relative abundance of the top two biofilm species, the less pathogenic Fusobacterium nucleatum and the caries-associated Streptococcus salivarius.

For the protein-repellent PSB coating, the error bars of the data were substantially larger than for the other sample types in most cases. This can be explained by the $\mathrm{pH}-$ independent anti-adhesive properties of this material, which slowed down the initial bacterial adhesion dramatically, as seen in the RNA amount. However, once the initial adhesion (of bacteria, debris of dead bacteria, or other biomolecules) has occurred, the bacteria can also grow exponentially on this layer. When this process differs on each sample, e.g., due to slightly different environmental conditions, this could result in larger errors compared to the potentially adhesive SMAMP, PZI, and uncoated substrates. Interestingly, there are some bacteria that show bacterial counts in the order PSB $>$ SMAMP $>/ \approx \mathbf{P Z I}$ (e.g., $V$. dispar) while others show the exact opposite trend (A. radicidentis, F. nucleatum, $N$. subflava), and yet others show no trend at all. This indicates a complex interplay between the surface features and the microbiological features of the individual bacterial species, particularly in a complex mixture like saliva, which is not yet fully understood at present. 
Campylobacter spp. seem able to colonize the protein-repellent PSB coating more easily than, for example, Fusobacterium nucleatum, whose abundance is reduced by almost half on PSB coating. On the other hand, the relative abundance Streptococcus salivarius (associated with caries) $[1,8]$ and the two Megasphaera species M. stantonii and M. elsdenii, seems less affected (although the PSB error bars are large for these species), thus indicating no decisive preference for either substrate. The proportions of certain Veillonella spp. also indicate that the polymer coatings facilitate the adhesion of these three species, irrespective of their type of bioactivity, albeit at low levels. This stresses that some microbial members of the biofilms are not affected by any of the coatings. The microbiome analysis by means of $16 \mathrm{~S}$ rRNA sequencing used here has been accepted and recommended to deliver a realistic composition of microbial niches, thereby including those species that cannot be cultivated using culture techniques. However, the 16S rRNA number is also dependent on the number of active bacteria, which includes more ribosomes and could thus lead to false positive abundance values of certain bacterial cells. Nevertheless, one advantage of this technique is that the revealed abundance number reflects the live as opposed to the dead bacteria. This is an important aspect when the antimicrobial activity of polymers on biofilm formation has to be investigated.

In summary, the tested materials modified the microbial composition of the biofilm formed by total salivary bacteria in different ways. From a clinical and ecological perspective, alternative treatment methods of oral biofilms in which the oral microbiota are modulated towards the healthy equilibrium are required. In this context, the present results are encouraging, since some bacterial members such as Tannerella forsythia, Prevotella denticola, and Fusobacterium nucleatum associated with poor oral health were reduced by the coatings, whereas other species belonging to the physiological resident flora such as some Streptococcus species and Neisseria mucosa were not affected. Hence, the present results encourage evaluating the clinical relevance of the tested coatings in situ.

\section{Conclusions}

The surface coatings PSB, PZI, and SMAMP analyzed in this study exhibited differential ability to reduce biofilm formation upon challenge with a complex bacterial mixture obtained from saliva. Although none of them prevented the formation of the biofilm, there was a drastic reduction in the overall amount of surface-attached bacteria, as well as the microbial composition of biofilm. Notably, the two protein-repellent coatings PSB and PZI reduced the amount of biofilm by one order of magnitude after $72 \mathrm{~h}$, while the mildly antimicrobial coating SMAMP only had a $40 \%$ reduction. This is an indication that coatings with protein repellency may be more efficient in reducing biofilm formation in situations where there is a high load of bacteria — such as in the oral cavity-than antimicrobial coatings. Additionally, for maintaining oral health, eliminating all bacteria in the oral cavity is not desired due to the existing synergism between the host and the microbiome. Thus, the ability to induce microbiome modification could be a much more desirable property than the ability to eliminate biofilms. Especially the reduction of some bacterial species associated with poor oral health such as Tannerella forsythia (observed for PSB and SMAMP), Fusobacterium nucleatum (also observed for PSB and SMAMP), and Prevotella denticola (observed for all coatings) may positively modulate the oral biofilm also in situ, which should be tested in further studies. Additionally, due to the association of Staphylococcus spp. with peri-implantitis on titanium-based oral implants and possible antibiotic resistance of these species, the lower abundance of these bacteria with the coatings is encouraging to further evaluate the biofilm formation ability of Staphylococcus aureus and Staphylococcus epidermidis on all tested coatings.

Further studies into such modulation of biofilm composition by surface coatings could enable developing surfaces that provide both a strong reduction in biofilm formation and a modulation of biofilm composition that favors non-harmful bacteria over pathogenic species. 
Supplementary Materials: The following are available online at https://www.mdpi.com/article/10 .3390 / microorganisms 9071427 / s1, Table S1: Total RNA extracted from biofilm samples grown on PSB, PZI, and SMAMP, uncoated substrates (NegCtrol), and uncoated substrates grown in the presence of chlorhexidine digluconate (CHX). Data is as concentration (in $\mathrm{ng} / \mu \mathrm{l}$ ), total mass of extracted RNA (in ng), and relative percentage compared to the mean of the uncoated samples (NegCtrol), i.e. the natively biofilm grown., Table S2: Abundance of bacteria (in counts per million, CPM, and percent), found in (a) saliva, (b) the native biofilm formed on uncoated substrates, and (c) the biofilms formed on uncoated substrates in the presence of CHX, listed as Top 20 genera. STD = Standard Deviation. It should be kept in mind that the amount of $16 \mathrm{~S}$ rRNA also correlates to a high number of ribosomes, which in turn correlates with the activity of bacteria, since active bacterial cells contain a higher number of ribosomes than inactive ones, Table S3: Abundance of bacteria (in counts per million, CPM, and percent), found in (a) saliva, (b) the native biofilm formed on uncoated substrates, and (c) the biofilms formed on uncoated substrates in the presence of CHX, listed as Top 20 species. STD = Standard Deviation. It should be kept in mind that the amount of 16S rRNA also correlates to a high number of ribosomes, which in turn correlates with the activity of bacteria, since active bacterial cells contain a higher number of ribosomes than inactive ones, Table S4: Abundance of bacteria (in counts per million, CPM, and percent), found in (a) biofilms grown on PSB, (b) biofilms grown on PZI, and (c) biofilms grown on SMAMP, listed as Top 20 genera. STD = Standard Deviation. It should be kept in mind that the amount of $16 \mathrm{~S}$ rRNA also correlates to a high number of ribosomes, which in turn correlates with the activity of bacteria, since active bacterial cells contain a higher number of ribosomes than inactive ones, Table S5: Abundance of bacteria (in counts per million, CPM, and percent), found in (a) biofilms grown on PSB, (b) biofilms grown on PZI, and (c) biofilms grown on SMAMP, listed as Top 20 species. STD = Standard Deviation. It should be kept in mind that the amount of $16 \mathrm{~S}$ rRNA also correlates to a high number of ribosomes, which in turn correlates with the activity of bacteria, since active bacterial cells contain a higher number of ribosomes than inactive ones, Table S6: About 950,000 to 1,500,000 sequencing reads passing the ONT Q7 quality score were obtained for each sample, and of these $>95 \%$ in each sample mapped to bacterial sequences as per the centrifuge results, Figure S1: Z-section galleries of representative confocal laser scanning microscopic (CLSM) images depicting the ex vivo biofilm formation (3 days) after live/dead staining. The panels illustrate the live (green) and dead (red) microbial populations of biofilms grown on the PSB coating. The multiple Z-sections in the panels were generated by vertical sectioning at $2.0-\mu \mathrm{m}$ intervals through the sample above the PSB surface. Bars, $20 \mu \mathrm{m}$.", Figure S2: Alpha (A) and beta (B) diversity measures were calculated using the $\mathrm{R}$ package vegan (Community Ecology Package, $\mathrm{R}$ package version 2.5-7., https: / /CRAN.R-project.org/package=vegan, published by J. Oksanen, F. Guillaume Blanchet, Michael Friendly, Roeland Kindt, Pierre Legendre, Dan McGlinn, Peter R. Minchin, R. B. O'Hara, Gavin L. Simpson, Peter Solymos, M. Henry H. Stevens, Eduard Szoecs and Helene Wagner 2020 accessed on 1 March 2021) and visualized using the ggplot and pheatmap packages (Raivo Kolde 2019: R package version 1.0.12. https: / CRAN.R-project.org/package=pheatmap accesed on 1 March 2021).

Author Contributions: A.A.-A., K.L. and O.S.: contributed to the conception and design of the study, data analysis, drafted and critically revised the manuscript. K.W., S.R., D.L.G.S. and S.P.: conducted the experiments. All authors have read and agreed to the published version of the manuscript.

Funding: This study was supported by the German Federal Ministry of Science and Education (Bundesministerium für Bildung und Forschung) through the projects Antibug (03VP03860) and BioSMAMPs (13XP5070).

Institutional Review Board Statement: The study protocol was approved by the Ethics Committee of the University of Freiburg (Nr. 381/15 and 91/15). All experiments and data collections were performed in accordance with relevant guidelines and regulations.

Informed Consent Statement: Written informed consent was obtained from all participants.

Data Availability Statement: The data are available on request from the authors.

Acknowledgments: Bettina Spitzmüller is acknowledged for her skillful technical laboratory assistance.

Conflicts of Interest: The authors declare no conflict of interest. The funders had no role in the design of the study; in the collection, analyses, or interpretation of data; in the writing of the manuscript, or in the decision to publish the results. 


\section{References}

1. Anderson, A.C.; Rothballer, M.; Altenburger, M.J.; Woelber, J.P.; Karygianni, L.; Vach, K.; Hellwig, E.; Al-Ahmad, A. Long-term fluctuation of oral biofilm microbiota following different dietary phases. Appl. Environ. Microbiol. 2020, 86, e01421-20. [CrossRef]

2. Corby, P.M.; Lyons-Weiler, J.; Bretz, W.A.; Hart, T.C.; Aas, J.A.; Boumenna, T.; Goss, J.; Corby, A.L.; Junior, H.M.; Weyant, R.J.; et al. Microbial risk indicators of early childhood caries. J. Clin. Microbiol. 2005, 43, 5753. [CrossRef] [PubMed]

3. Grier, A.; Myers, J.A.; O'Connor, T.G.; Quivey, R.G.; Gill, S.R.; Kopycka-Kedzierawski, D.T. Oral microbiota composition predicts early childhood caries onset. J. Dent. Res. 2020. [CrossRef]

4. Anderson, A.C.; Al-Ahmad, A.; Schlueter, N.; Frese, C.; Hellwig, E.; Binder, N. Influence of the long-term use of oral hygiene products containing stannous ions on the salivary microbiome-A randomized controlled trial. Sci. Rep. 2020, 10, 9546. [CrossRef]

5. Kumar, P.S.; Griffen, A.L.; Moeschberger, M.L.; Leys, E.J. Identification of candidate periodontal pathogens and beneficial species by quantitative 16s clonal analysis. J. Clin. Microbiol. 2005, 43, 3944. [CrossRef] [PubMed]

6. Zaura, E.; Brandt, B.W.; Prodan, A.; Teixeira de Mattos, M.J.; Imangaliyev, S.; Kool, J.; Buijs, M.J.; Jagers, F.L.P.W.; HennequinHoenderdos, N.L.; Slot, D.E.; et al. On the ecosystemic network of saliva in healthy young adults. ISME J. 2017, 11, 1218-1231. [CrossRef]

7. Papapanou, P.N.; Susin, C. Periodontitis epidemiology: Is periodontitis under-recognized, over-diagnosed, or both? Periodontol 2000 2017, 75, 45-51. [CrossRef]

8. Takahashi, N.; Nyvad, B. Caries ecology revisited: Microbial dynamics and the caries process. Caries Res. 2008, 42, 409-418. [CrossRef]

9. Torrungruang, K.; Jitpakdeebordin, S.; Charatkulangkun, O.; Gleebbua, Y. Porphyromonas gingivalis, aggregatibacter actinomycetemcomitans, and treponema denticola / prevotella intermedia co-infection are associated with severe periodontitis in a thai population. PLoS ONE 2015, 10, e0136646. [CrossRef] [PubMed]

10. Miralda, I.; Uriarte, S.M. Periodontal pathogens' strategies disarm neutrophils to promote dysregulated inflammation. Mol. Oral Microbiol. 2020, 36, 103-120. [CrossRef] [PubMed]

11. Belibasakis, G.N.; Manoil, D. Microbial community-driven etiopathogenesis of peri-implantitis. J. Dent. Res. 2020, 100, 21-28. [CrossRef] [PubMed]

12. Al-Ahmad, A.; Muzafferiy, F.; Anderson, A.C.; Wölber, J.P.; Ratka-Krüger, P.; Fretwurst, T.; Nelson, K.; Vach, K.; Hellwig, E. Shift of microbial composition of peri-implantitis-associated oral biofilm as revealed by $16 \mathrm{~s}$ rrna gene cloning. J. Med. Microbiol. 2018, 67, 332-340. [CrossRef] [PubMed]

13. Belibasakis, G.N.; Mir-Mari, J.; Sahrmann, P.; Sanz-Martin, I.; Schmidlin, P.R.; Jung, R.E. Clinical association of spirochaetes and synergistetes with peri-implantitis. Clin. Oral. Implant. Res. 2016, 27, 656-661. [CrossRef]

14. Mark Welch, J.L.; Rossetti, B.J.; Rieken, C.W.; Dewhirst, F.E.; Borisy, G.G. Biogeography of a human oral microbiome at the micron scale. Proc. Natl. Acad. Sci. USA 2016, 113, E791-E800. [CrossRef] [PubMed]

15. Sultan, A.S.; Kong, E.F.; Rizk, A.M.; Jabra-Rizk, M.A. The oral microbiome: A lesson in coexistence. PLoS Pathog. 2018, 14, e1006719. [CrossRef] [PubMed]

16. Hannig, C.; Hannig, M. The oral cavity-A key system to understand substratum-dependent bioadhesion on solid surfaces in man. Clin. Oral. Investig. 2009, 13, 123-139. [CrossRef]

17. Kolenbrander, P.E.; Palmer, R.J.; Periasamy, S.; Jakubovics, N.S. Oral multispecies biofilm development and the key role of cell-cell distance. Nat. Rev. Microbiol. 2010, 8, 471-480. [CrossRef] [PubMed]

18. Hannig, C.; Hannig, M.; Rehmer, O.; Braun, G.; Hellwig, E.; Al-Ahmad, A. Fluorescence microscopic visualization and quantification of initial bacterial colonization on enamel in situ. Arch. Oral. Biol. 2007, 52, 1048-1056. [CrossRef] [PubMed]

19. Al-Ahmad, A.; Wunder, A.; Auschill, T.M.; Follo, M.; Braun, G.; Hellwig, E.; Arweiler, N.B. The in vivo dynamics of streptococcus spp., actinomyces naeslundii, fusobacterium nucleatum and veillonella spp. In dental plaque biofilm as analysed by five-colour multiplex fluorescence in situ hybridization. J. Med. Microbiol. 2007, 56, 681-687. [CrossRef]

20. Cugini, C.; Shanmugam, M.; Landge, N.; Ramasubbu, N. The role of exopolysaccharides in oral biofilms. J. Dent. Res. 2019, 98, 739-745. [CrossRef] [PubMed]

21. Mah, T.F.; O'Toole, G.A. Mechanisms of biofilm resistance to antimicrobial agents. Trends Microbiol. 2001, 9, 34-39. [CrossRef]

22. Stewart, P.S.; William, C.J. Antibiotic resistance of bacteria in biofilms. Lancet 2001, 358, 135-138. [CrossRef]

23. Chambless, J.D.; Hunt, S.M.; Stewart, P.S. A three-dimensional computer model of four hypothetical mechanisms protecting biofilms from antimicrobials. Appl. Environ. Microbiol. 2006, 72, 2005-2013. [CrossRef] [PubMed]

24. Busscher, H.J.; van der Mei, H.C.; Subbiahdoss, G.; Jutte, P.C.; van den Dungen, J.J.A.M.; Zaat, S.A.J.; Schultz, M.J.; Grainger, D.W. Biomaterial-associated infection: Locating the finish line in the race for the surface. Sci. Transl. Med. 2012, 4. [CrossRef]

25. Zhang, Y.; Liu, Y.; Ren, B.; Zhang, D.; Xie, S.; Chang, Y.; Yang, J.; Wu, J.; Xu, L.; Zheng, J. Fundamentals and applications of zwitterionic antifouling polymers. J. Phys. D Appl. Phys. 2019, 52, 403001. [CrossRef]

26. Banerjee, I.; Pangule, R.C.; Kane, R.S. Antifouling coatings: Recent developments in the design of surfaces that prevent fouling by proteins, bacteria, and marine organisms. Adv. Mater. 2011, 23, 690-718. [CrossRef]

27. Krishnan, S.; Weinman, C.J.; Ober, C.K. Advances in polymers for anti-biofouling surfaces. J. Mater. Chem. 2008, $18,3405-3413$. [CrossRef]

28. Paschke, S.; Lienkamp, K. Polyzwitterions: From surface properties and bioactivity profiles to biomedical applications. ACS Appl. Polym. Mater. 2020, 2, 129-151. [CrossRef] 
29. Jain, A.; Duvvuri, L.S.; Farah, S.; Beyth, N.; Domb, A.J.; Khan, W. Antimicrobial polymers. Adv. Healthc. Mater. 2014, 3, $1969-1985$. [CrossRef]

30. Lienkamp, K.; Madkour, A.E.; Tew, G.N. Antibacterial peptidomimetics: Polymeric synthetic mimics of antimicrobial peptides. Adv. Polym. Sci. 2013, 251, 141-172.

31. Siedenbiedel, F; Tiller, J.C. Antimicrobial polymers in solution and on surfaces: Overview and functional principles. Polymers 2012, 4, 46-71. [CrossRef]

32. Claesson, R.; Sjögren, U.; Esberg, A.; Brundin, M.; Granlund, M. Actinomyces radicidentis and actinomyces haliotis, coccoid actinomyces species isolated from the human oral cavity. Anaerobe 2017, 48, 19-26. [CrossRef]

33. de Oliveira, R.V.; Bonafé, F.S.; Spolidorio, D.M.; Koga-Ito, C.Y.; de Farias, A.L.; Kirker, K.R.; James, G.A.; Brighenti, F.L. Streptococcus mutans and actinomyces naeslundii interaction in dual-species biofilm. Microorganisms 2020, 8, 194. [CrossRef] [PubMed]

34. Dige, I.; Raarup, M.K.; Nyengaard, J.R.; Kilian, M.; Nyvad, B. Actinomyces naeslundii in initial dental biofilm formation. Microbiology 2009, 155, 2116-2126. [CrossRef] [PubMed]

35. Henssge, U.; Do, T.; Radford, D.R.; Gilbert, S.C.; Clark, D.; Beighton, D. Emended description of actinomyces naeslundii and descriptions of actinomyces oris sp. Nov. And actinomyces johnsonii sp. Nov., previously identified as actinomyces naeslundii genospecies 1, 2 and wva 963. Int. J. Syst. Evol. Microbiol. 2009, 59, 509-516. [CrossRef]

36. Collins, M.D.; Hoyles, L.; Kalfas, S.; Sundquist, G.; Monsen, T.; Nikolaitchouk, N.; Falsen, E. Characterization of actinomyces isolates from infected root canals of teeth: Description of actinomyces radicidentis. J. Clin. Microbiol. 2000, 38, 3399-3403. [CrossRef] [PubMed]

37. Colombo, A.P.; Boches, S.K.; Cotton, S.L.; Goodson, J.M.; Kent, R.; Haffajee, A.D.; Socransky, S.S.; Hasturk, H.; Van Dyke, T.E.; Dewhirst, F.; et al. Comparisons of subgingival microbial profiles of refractory periodontitis, severe periodontitis, and periodontal health using the human oral microbe identification microarray. J. Periodontol. 2009, 80, 1421-1432. [CrossRef]

38. Liu, F.; Ma, R.; Wang, Y.; Zhang, L. The clinical importance of campylobacter concisus and other human hosted campylobacter species. Front. Cell. Infect. Microbiol. 2018, 8, 243. [CrossRef] [PubMed]

39. Lee, S.; Lee, J.; Ha, J.; Choi, Y.; Kim, S.; Lee, H.; Yoon, Y.; Choi, K.-H. Clinical relevance of infections with zoonotic and human oral species of campylobacter. J. Microbiol. 2016, 54, 459-467. [CrossRef]

40. Basic, A.; Enerbäck, H.; Waldenström, S.; Östgärd, E.; Suksuart, N.; Dahlen, G. Presence of helicobacter pylori and campylobacter ureolyticus in the oral cavity of a northern thailand population that experiences stomach pain. J. Oral. Microbiol. 2018, 10, 1527655. [CrossRef] [PubMed]

41. Tsuzukibashi, O.; Uchibori, S.; Shinozaki-Kuwahara, N.; Kobayashi, T.; Takada, K.; Hirasawa, M. A selective medium for the isolation of corynebacterium species in oral cavities. J. Microbiol. Methods 2014, 104, 67-71. [CrossRef] [PubMed]

42. Morio, F.; Jean-Pierre, H.; Dubreuil, L.; Jumas-Bilak, E.; Calvet, L.; Mercier, G.; Devine, R.; Marchandin, H. Antimicrobial susceptibilities and clinical sources of dialister species. Antimicrob. Agents Chemother. 2007, 51, 4498-4501. [CrossRef]

43. Komiyama, E.Y.; Lepesqueur, L.S.S.; Yassuda, C.G.; Samaranayake, L.P.; Parahitiyawa, N.B.; Balducci, I.; Koga-Ito, C.Y. Enterococcus species in the oral cavity: Prevalence, virulence factors and antimicrobial susceptibility. PLoS ONE 2016, 11, e0163001. [CrossRef] [PubMed]

44. Han, Y.W. Fusobacterium nucleatum: A commensal-turned pathogen. Curr. Opin. Microbiol. 2015, 23, 141-147. [CrossRef]

45. Krishnan, K.; Chen, T.; Paster, B.J. A practical guide to the oral microbiome and its relation to health and disease. Oral. Dis. 2017, 23, 276-286. [CrossRef] [PubMed]

46. Wang, Q.; Chen, X.; Hu, H.; Wei, X.; Wang, X.; Peng, Z.; Ma, R.; Zhao, Q.; Zhao, J.; Liu, J.; et al. Structural changes in the oral microbiome of the adolescent patients with moderate or severe dental fluorosis. Sci. Rep. 2021, 11, 2897. [CrossRef]

47. Park, S.-N.; Lim, Y.K.; Shin, J.H.; Kim, H.-S.; Jo, E.; Lee, W.-P.; Shin, Y.; Paek, J.; Chang, Y.-H.; Kim, H.; et al. Fusobacterium pseudoperiodonticum sp. Nov., isolated from the human oral cavity. Curr. Microbiol. 2019, 76, 659-665. [CrossRef]

48. Wasfi, R.; Abd El-Rahman, O.A.; Zafer, M.M.; Ashour, H.M. Probiotic lactobacillus sp. Inhibit growth, biofilm formation and gene expression of caries-inducing streptococcus mutans. J. Cell. Mol. Med. 2018, 22, 1972-1983. [CrossRef]

49. Obata, J.; Takeshita, T.; Shibata, Y.; Yamanaka, W.; Unemori, M.; Akamine, A.; Yamashita, Y. Identification of the microbiota in carious dentin lesions using 16s rrna gene sequencing. PLOS ONE 2014, 9, e103712.

50. Park, O.-J.; Jeong, M.-H.; Lee, E.-H.; Cho, M.-R.; Hwang, J.; Cho, S.; Yun, C.-H.; Han, S.H.; Kim, S.-Y. A pilot study of chronological microbiota changes in a rat apical periodontitis model. Microorganisms 2020, 8, 1174. [CrossRef]

51. Lim, Y.K.; Park, S.-N.; Lee, W.-P.; Shin, J.H.; Jo, E.; Shin, Y.; Paek, J.; Chang, Y.-H.; Kim, H.; Kook, J.-K. Lautropia dentalis sp. Nov., isolated from human dental plaque of a gingivitis lesion. Curr. Microbiol. 2019, 76, 1369-1373. [CrossRef] [PubMed]

52. Mashima, I.; Nakazawa, F. Interaction between Streptoccocus spp. and Veillonella tobetsuensis in the early stages of oral biofilm formation. J. Bacteriol. 2015, 197, 2104-2111. [CrossRef] [PubMed]

53. Donati, C.; Zolfo, M.; Albanese, D.; Truong, D.T.; Asnicar, F.; Iebba, V.; Cavalieri, D.; Jousson, O.; De Filippo, C.; Huttenhower, C.; et al. Uncovering oral neisseria tropism and persistence using metagenomic sequencing. Nat. Microbiol. 2016, 1, 16070. [CrossRef]

54. Mysak, J.; Podzimek, S.; Sommerova, P.; Lyuya-Mi, Y.; Bartova, J.; Janatova, T.; Prochazkova, J.; Duskova, J. Porphyromonas gingivalis: Major periodontopathic pathogen overview. J. Immunol. Res. 2014, 2014, 476068. [CrossRef]

55. Zhong, E.F.; Chang, A.; Stucky, A.; Chen, X.; Mundluru, T.; Khalifeh, M.; Sedghizadeh, P.P. Genomic analysis of oral lichen planus and related oral microbiome pathogens. Pathogens 2020, 9, 952. [CrossRef] 
56. Kondo, Y.; Sato, K.; Nagano, K.; Nishiguchi, M.; Hoshino, T.; Fujiwara, T.; Nakayama, K. Involvement of pork, a component of the type ix secretion system, in prevotella melaninogenica pathogenicity. Microbiol. Immunol. 2018, 62, 554-566. [CrossRef] [PubMed]

57. Amer, A.; Whelan, A.; Al-Hebshi, N.N.; Healy, C.M.; Moran, G.P. Acetaldehyde production by rothia mucilaginosa isolates from patients with oral leukoplakia. J. Oral. Microbiol. 2020, 12, 1743066. [CrossRef] [PubMed]

58. Huse, H.K.; Miller, S.A.; Chandrasekaran, S.; Hindler, J.A.; Lawhon, S.D.; Bemis, D.A.; Westblade, L.F.; Humphries, R.M. Evaluation of oxacillin and cefoxitin disk diffusion and mic breakpoints established by the clinical and laboratory standards institute for detection of meca-mediated oxacillin resistance in staphylococcus schleiferi. J. Clin. Microbiol 2018, 56, e01653-17. [CrossRef]

59. Duan, D.; Scoffield, J.A.; Zhou, X.; Wu, H. Fine-tuned production of hydrogen peroxide promotes biofilm formation of streptococcus parasanguinis by a pathogenic cohabitant aggregatibacter actinomycetemcomitans. Environ. Microbiol. 2016, 18, 4023-4036. [CrossRef] [PubMed]

60. Vieira Colombo, A.P.; Magalhães, C.B.; Hartenbach, F.A.; do Souto, R.M.; da Silva-Boghossian, C.M. Periodontal-diseaseassociated biofilm: A reservoir for pathogens of medical importance. Microb. Pathog. 2016, 94, 27-34. [CrossRef]

61. Sousa, V.; Nibali, L.; Spratt, D.; Dopico, J.; Mardas, N.; Petrie, A.; Donos, N. Peri-implant and periodontal microbiome diversity in aggressive periodontitis patients: A pilot study. Clin. Oral. Implant. Res. 2017, 28, 558-570. [CrossRef]

62. Vartoukian, S.R.; Moazzez, R.V.; Paster, B.J.; Dewhirst, F.E.; Wade, W.G. First cultivation of health-associated tannerella sp. Hot-286 (bu063). J. Dent. Res. 2016, 95, 1308-1313. [CrossRef]

63. Kurowska, M.; Eickenscheidt, A.; Guevara-Solarte, D.L.; Widyaya, V.T.; Marx, F.; Al-Ahmad, A.; Lienkamp, K. A simultaneously antimicrobial, protein-repellent and cell-compatible polyzwitterion network. Biomacromolecules 2017, 18, 1373-1386. [CrossRef]

64. Kurowska, M.; Eickenscheidt, A.; Al-Ahmad, A.; Lienkamp, K. Simultaneously antimicrobial, protein-repellent and cellcompatible polyzwitterion networks: More insight on bioactivity and physical properties. ACS Appl. Bio Mater. 2018, 1, 613-626. [CrossRef]

65. Zou, P.; Laird, D.; Riga, E.K.; Deng, Z.; Perez-Hernandez, H.-R.; Guevara-Solarte, D.L.; Steinberg, T.; Al-Ahmad, A.; Lienkamp, K. Antimicrobial and cell-compatible surface-attached polymer networks-How the correlation of chemical structure to physical and biological data leads to a modified mechanism of action. J. Mater. Chem. B 2015, 3, 6224-6238. [CrossRef]

66. Syed, S.A.; Loesche, W.J. Survival of human dental plaque flora in various transport media. Appl. Microbiol. 1972, 24, 638-644. [CrossRef] [PubMed]

67. Heuer, H.; Krsek, M.; Baker, P.; Smalla, K.; Wellington, E.M. Analysis of actinomycete communities by specific amplification of genes encoding 16s rrna and gel-electrophoretic separation in denaturing gradients. Appl. Environ. Microbiol. 1997, 63, 3233-3241. [CrossRef] [PubMed]

68. Kim, D.; Song, L.; Breitwieser, F.P.; Salzberg, S.L. Centrifuge: Rapid and sensitive classification of metagenomic sequences. Genome Res. 2016, 26, 1721-1729. [CrossRef]

69. Team, R.C. R: A Language and Environment for Statistical Computing. Available online: http://www.R-project.org/ (accessed on 15 February 2020).

70. Breitwieser, F.P.; Salzberg, S.L. Pavian: Interactive analysis of metagenomics data for microbiomics and pathogen identification. bioRxiv 2016, 084715.

71. Wickham, H. Ggplot2_Elegant Graphics for Data Analysis; Springer International Publishing: Heidelberg, Germany, 2016.

72. Colak, S.; Tew, G.N. Dual-functional romp-based betaines: Effect of hydrophilicity and backbone structure on nonfouling properties. Langmuir 2012, 28, 666-675. [CrossRef] [PubMed]

73. Altmann, B.; Karygianni, L.; Al-Ahmad, A.; Butz, F.; Bächle, M.; Adolfsson, E.; Fürderer, T.; Courtois, N.; Palmero, P.; Follo, M.; et al. Assessment of novel long-lasting ceria-stabilized zirconia-based ceramics with different surface topographies as implant materials. Adv. Funct. Mater. 2017, 27, 1702512. [CrossRef]

74. Li, R.; Tun, H.M.; Jahan, M.; Zhang, Z.; Kumar, A.; Dilantha Fernando, W.G.; Farenhorst, A.; Khafipour, E. Comparison of DNA-, pma-, and rna-based 16s rrna illumina sequencing for detection of live bacteria in water. Sci. Rep. 2017, 7, 5752. [CrossRef]

75. Shiga, Y.; Hosomi, N.; Nezu, T.; Nishi, H.; Aoki, S.; Nakamori, M.; Ishikawa, K.; Kinoshita, N.; Imamura, E.; Ueno, H.; et al. Association between periodontal disease due to campylobacter rectus and cerebral microbleeds in acute stroke patients. PLoS ONE 2020, 15, e0239773. [CrossRef] [PubMed]

76. Al-Ahmad, A.; Maier, J.; Follo, M.; Spitzmüller, B.; Wittmer, A.; Hellwig, E.; Hübner, J.; Jonas, D. Food-borne enterococci integrate into oral biofilm: An in vivo study. J. Endod. 2010, 36, 1812-1819. [CrossRef] [PubMed]

77. Persson, G.R.; Renvert, S. Cluster of bacteria associated with peri-implantitis. Clin. Implant. Dent. Relat. Res. 2014, 16, 783-793. [CrossRef]

78. Thurnheer, T.; Belibasakis, G.N. Incorporation of staphylococci into titanium-grown biofilms: An in vitro "submucosal" biofilm model for peri-implantitis. Clin. Oral. Implant. Res. 2016, 27, 890-895. [CrossRef]

79. Gilbert, P.; Moore, L.E. Cationic antiseptics: Diversity of action under a common epithet. J. Appl. Microbiol. 2005, 99, 703-715. [CrossRef]

80. McDonnell, G.; Russell, A.D. Antiseptics and disinfectants: Activity, action, and resistance. Clin. Microbiol. Rev. 1999, 12, 147-179. [CrossRef]

81. Sato-Suzuki, Y.; Washio, J.; Wicaksono, D.P.; Sato, T.; Fukumoto, S.; Takahashi, N. Nitrite-producing oral microbiome in adults and children. Sci. Rep. 2020, 10, 16652. [CrossRef] 
82. Park, M.K.; Shin, H.B. Massilia sp. Isolated from otitis media. Int. J. Pediatr. Otorhinolaryngol. 2013, 77, 303-305. [CrossRef]

83. Al-Hebshi, N.N.; Alharbi, F.A.; Mahri, M.; Chen, T. Differences in the bacteriome of smokeless tobacco products with different oral carcinogenicity: Compositional and predicted functional analysis. Genes 2017, 8, 106. [CrossRef] [PubMed]

84. Cieplik, F.; Jakubovics, N.S.; Buchalla, W.; Maisch, T.; Hellwig, E.; Al-Ahmad, A. Resistance toward chlorhexidine in oral bacteria-Is there cause for concern? Front. Microbiol. 2019, 10, 587. [CrossRef] [PubMed] 